Alaska Petroleum Studies Project

\title{
Geologic Model for Oil and Gas Assessment of the Kemik-Thomson Play, Central North Slope, Alaska
}

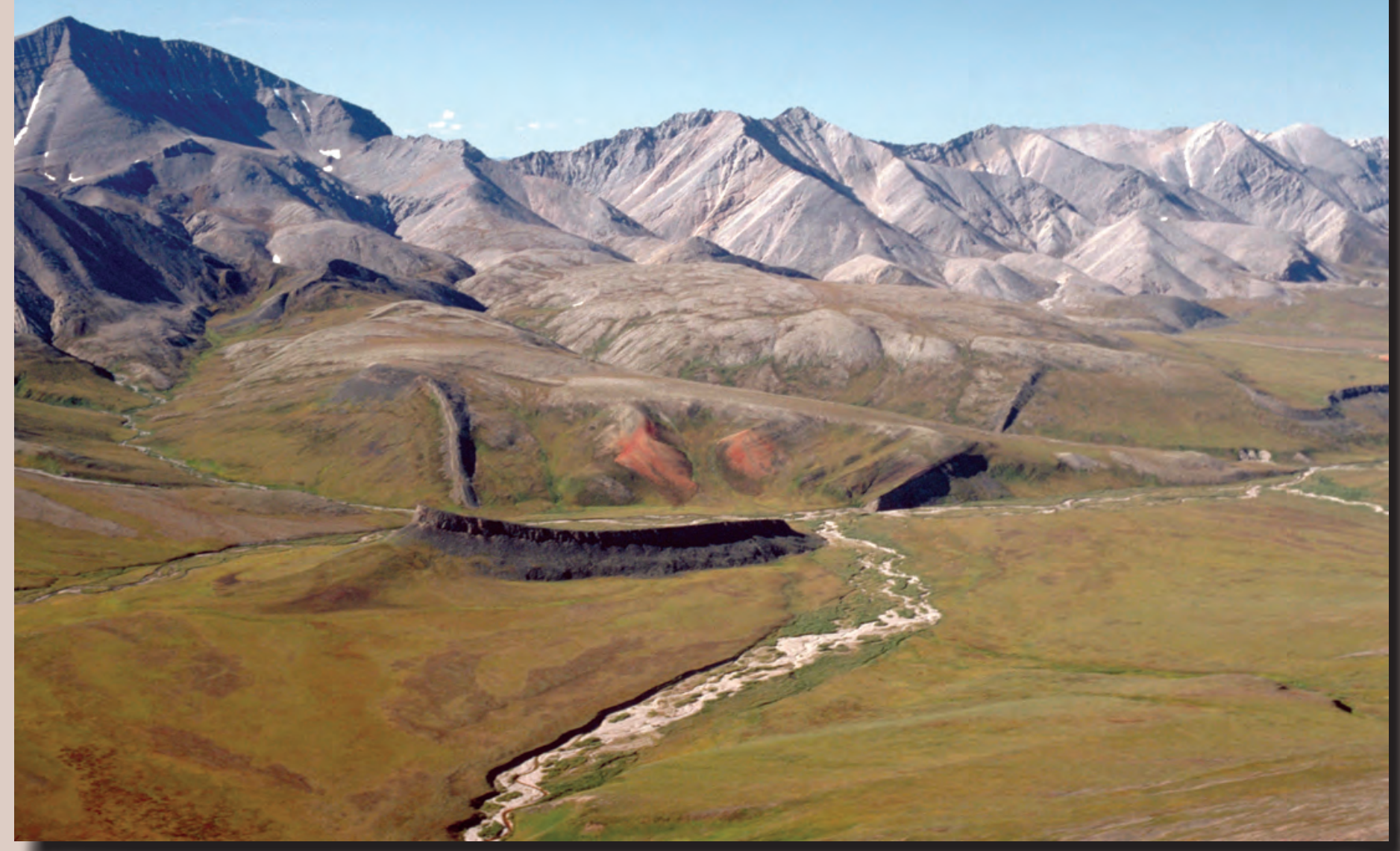

Scientific Investigations Report 2008-5146 
Cover: Photograph of the Ignek Valley in the Arctic National Wildlife Preserve (ANWR), looking southwest towards the Brooks Range. Kemik Sandstone is dark ridge in foreground; Hue Shale is reddish slope. Photograph by C.J. Schenk, August 9, 1995. 


\section{Geologic Model for Oil and Gas Assessment of the Kemik-Thomson Play, Central North Slope, Alaska}

By Christopher J. Schenk and David W. Houseknecht

Alaska Petroleum Studies Project

Scientific Investigations Report 2008-5146 


\section{U.S. Department of the Interior DIRK KEMPTHORNE, Secretary}

\section{U.S. Geological Survey \\ Mark D. Myers, Director}

\section{U.S. Geological Survey, Reston, Virginia: 2008}

For product and ordering information:

World Wide Web: http://www.usgs.gov/pubprod

Telephone: 1-888-ASK-USGS

For more information on the USGS--the Federal source for science about the Earth, its natural and living resources, natural hazards, and the environment:

World Wide Web: http://www.usgs.gov

Telephone: 1-888-ASK-USGS

Any use of trade, product, or firm names is for descriptive purposes only and does not imply endorsement by the U.S. Government.

Although this report is in the public domain, permission must be secured from the individual copyright owners to reproduce any copyrighted materials contained within this report.

Suggested citation:

Schenk, C.J., and Houseknecht, D.W., 2008, Geologic Model for Oil and Gas Assessment of the Kemik-Thomson Play, Central North Slope, Alaska: U.S. Geological Survey Scientific Investigations Report 2008-5146, 28 p. 


\section{Contents}

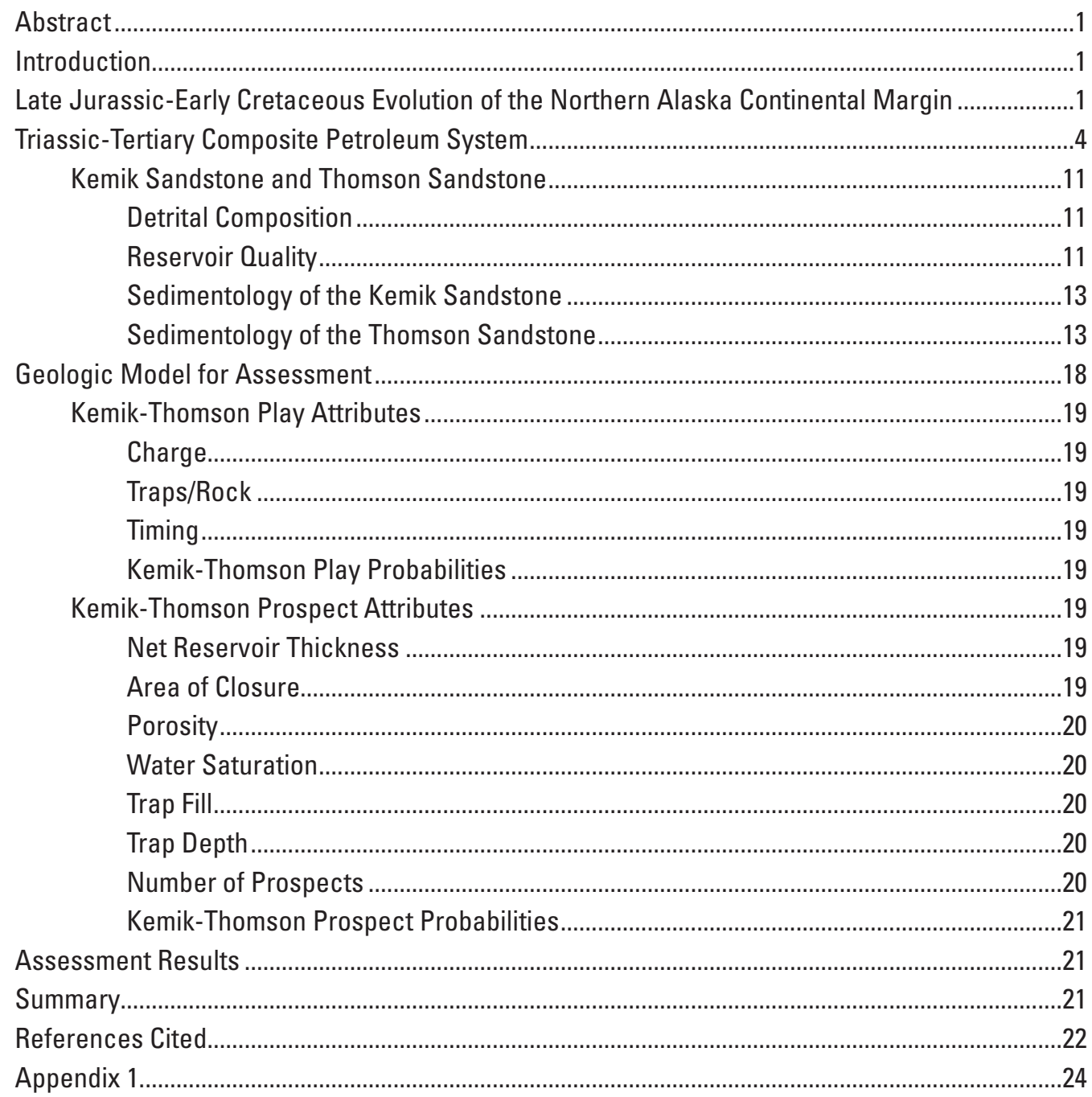




\section{Figures}

1. Map showing the Kemik-Thomson Play (gray area) in the northeastern part of the Central North Slope, Alaska ............................................................................

2. Stratigraphic column for the Central North Slope, Alaska .................................................

3-5. Maps Showing -

3. Distribution of rocks that subcrop the Lower Cretaceous

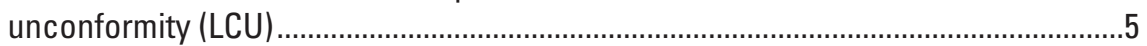

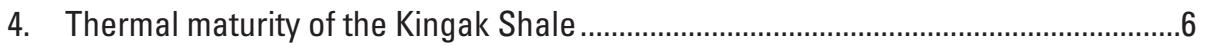

5. Thermal maturity of the Hue Shale (and pebble shale unit) .....................................

6. Burial-history plot of stratigraphic units in the Leffingwell \#1 well .................................. 8

7. Burial-history plot of stratigraphic units in the Bush Federal \#1 well ...............................9

8. Map showing postulated extent of the Triassic-Tertiary Composite

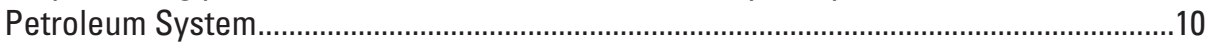

9. Selected photomicrographs of the Thomson sandstone .............................................12

10. Cross section illustrating facies of Kemik Sandstone ...................................................14

11. Seismic profile of possible Kemik Sandstone reservoir in the so-called Slugger Unit of the Central North Slope .....................................................................15

12. Borehole geophysical log cross section of the Thomson sandstone ..............................16

13. Plot of oil accumulation size from the Muddy Sandstone analog ..................................17

14. Events chart for the Triassic-Tertiary Composite Petroleum System ...............................18

\section{Tables}

1. Assessment results for the Kemik-Thomson Play. 


\title{
Geologic Model for Oil and Gas Assessment of the Kemik-Thomson Play, Central North Slope, Alaska
}

\author{
By Christopher J. Schenk and David W. Houseknecht
}

\begin{abstract}
A geologic model was developed to assess undiscovered oil and gas resources in the Kemik-Thomson Play of the Central North Slope, Alaska. In this model, regional erosion during the Early Cretaceous produced an incised valley system on the flanks and crest of the Mikkelsen High and formed the Lower Cretaceous unconformity. Locally derived, coarse-grained siliciclastic and carbonate detritus from eroded Franklinian-age basement rocks, Carboniferous Kekiktuk Conglomerate (of the Endicott Group), Lisburne Group, and Permian-Triassic Sadlerochit Group may have accumulated in the incised valleys during lowstand and transgression, forming potential reservoirs in the Lower Cretaceous Kemik Sandstone and Thomson sandstone (informal term). Continued transgression resulted in the deposition of the mudstones of the overlying Cretaceous pebble shale unit and Hue Shale, which form top seals to the potential reservoirs. Petroleum from thermally mature facies of the Triassic Shublik Formation, Jurassic Kingak Shale, Hue Shale (and pebble shale unit), and the Cretaceous-Tertiary Canning Formation might have charged Thomson and Kemik sandstone reservoirs in this play during the Tertiary. The success of this play depends largely upon the presence of reservoir-quality units in the Kemik Sandstone and Thomson sandstone.
\end{abstract}

\section{Introduction}

The Kemik-Thomson Play was defined to encompass a potential set of undiscovered oil and gas accumulations in the Lower Cretaceous Kemik Sandstone and Thomson sandstone (informal term) in the northeastern part of the Central North Slope of Alaska (fig. 1). The Kemik-Thomson Play is bounded to the north by the Alaska State waters-Federal waters boundary, to the east by the boundary with the 1002 area of the Arctic National Wildlife Refuge (ANWR), to the south by the boundary with the Beaufortian Structural Play, and to the west by the boundary with the Kuparuk Sandstone Play (fig. 1). The Kemik-Thomson Play comprises 1,803,516 acres, of which 1,476,683 acres are onshore in the Central North Slope and 326,833 acres are in the Alaska State waters.
The purpose of this paper is to present the geologic model that formed the basis for the assessment of undiscovered oil and gas resources in potential Kemik and Thomson sandstone reservoirs in the northeastern part of the Central North Slope and to document the geologic input parameters for the assessment. The geologic model is based on reservoir sedimentology and quality, trap types and timing, potential seals, and current knowledge of the petroleum systems in this play.

\section{Late Jurassic-Early Cretaceous Evolution of the Northern Alaska Continental Margin}

Several coeval Lower Cretaceous sandstones were deposited on the Lower Cretaceous unconformity (LCU) along the Alaskan North Slope; the Kemik Sandstone, Thomson sandstone, Kuparuk "C" sandstone, and the Put River Sandstone are the principal stratigraphic units (fig. 2). The Kuparuk "C" sandstone and Put River Sandstone occur west of the Kemik-Thomson Play area (Carman and Hardwick, 1983; Halgedahl and Jarrard, 1987; Masterson and Paris, 1987). The Kemik Sandstone, in particular, has been examined in the field since the first geological studies in the Central North Slope area (Leffingwell, 1919; Keller and others, 1961; Detterman and others, 1975). The source of these sandstones is generally considered to be a landmass that existed to the north prior to continental rifting, and the sandstones are generally included as part of the Jurassic-Lower Cretaceous Beaufortian stratigraphic sequence (fig. 2).

Deposition of the Kemik Sandstone, Thomson sandstone, and coeval units such as the Kuparuk " $\mathrm{C}$ " sandstone and the Put River Sandstone is closely linked to the tectonic evolution of the margin of northern Alaska in Late Jurassic and Early Cretaceous time (Carman and Hardwick, 1983; Noonan, 1987). The north margin of Alaska was a stable platform through much of Paleozoic to Late Jurassic time, a period during which crustal doming related to a presumed thermal anomaly in the mantle resulted in the formation of a pre-rift uplift called the Barrow Arch (Carman and Hardwick, 1983) and its eastern extension known as the Mikkelsen High (fig. 1). 


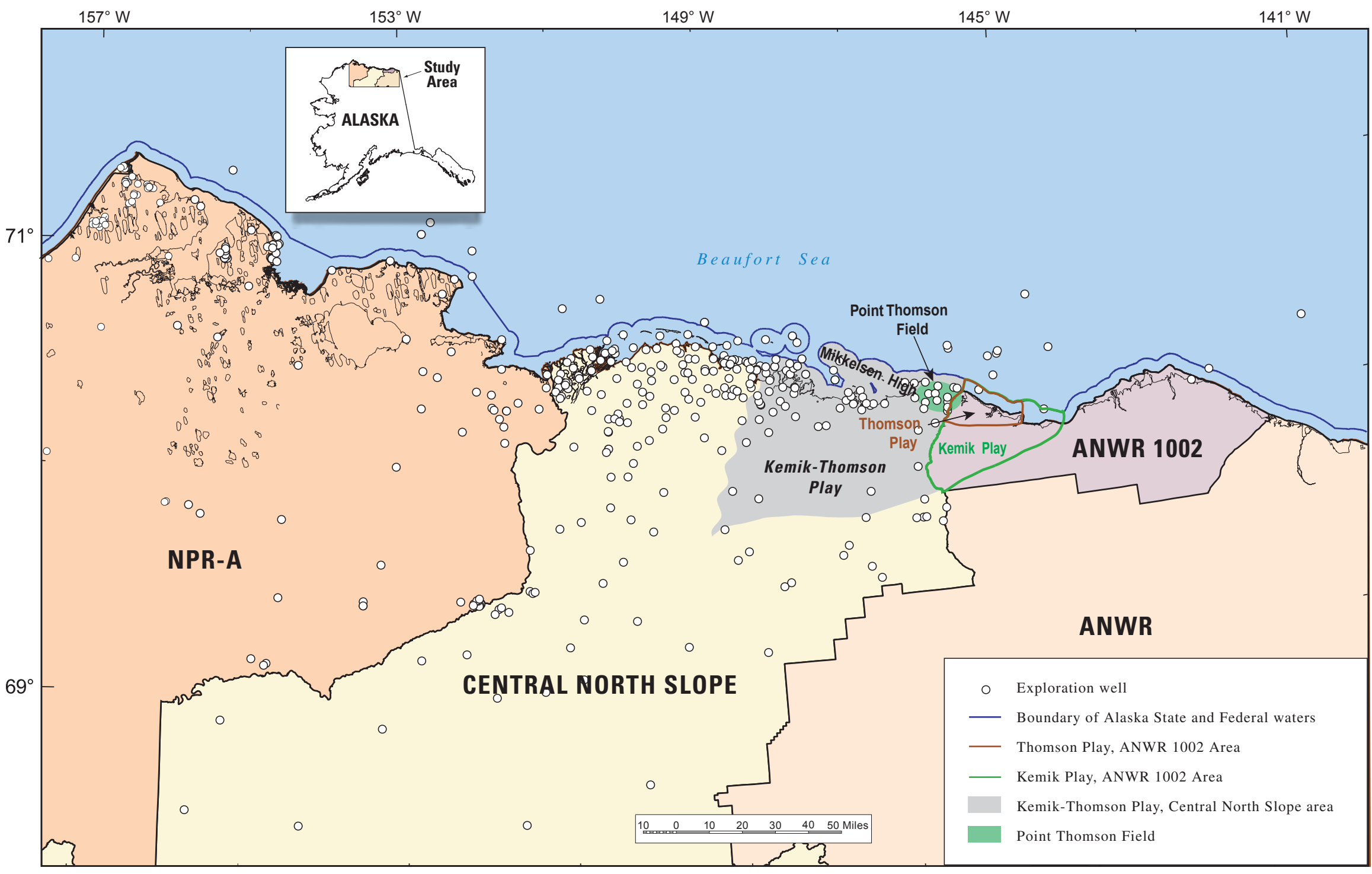

Figure 1. Map of the Kemik-Thomson Play (gray area) in the northeastern part of the Central North Slope, Alaska. NPR-A, National Petroleum Reserve-Alaska; ANWR, Arctic National Wildlife Refuge; ANWR 1002, 1002 area of the Arctic National Wildlife Refuge. Point Thomson Field shown in green. 


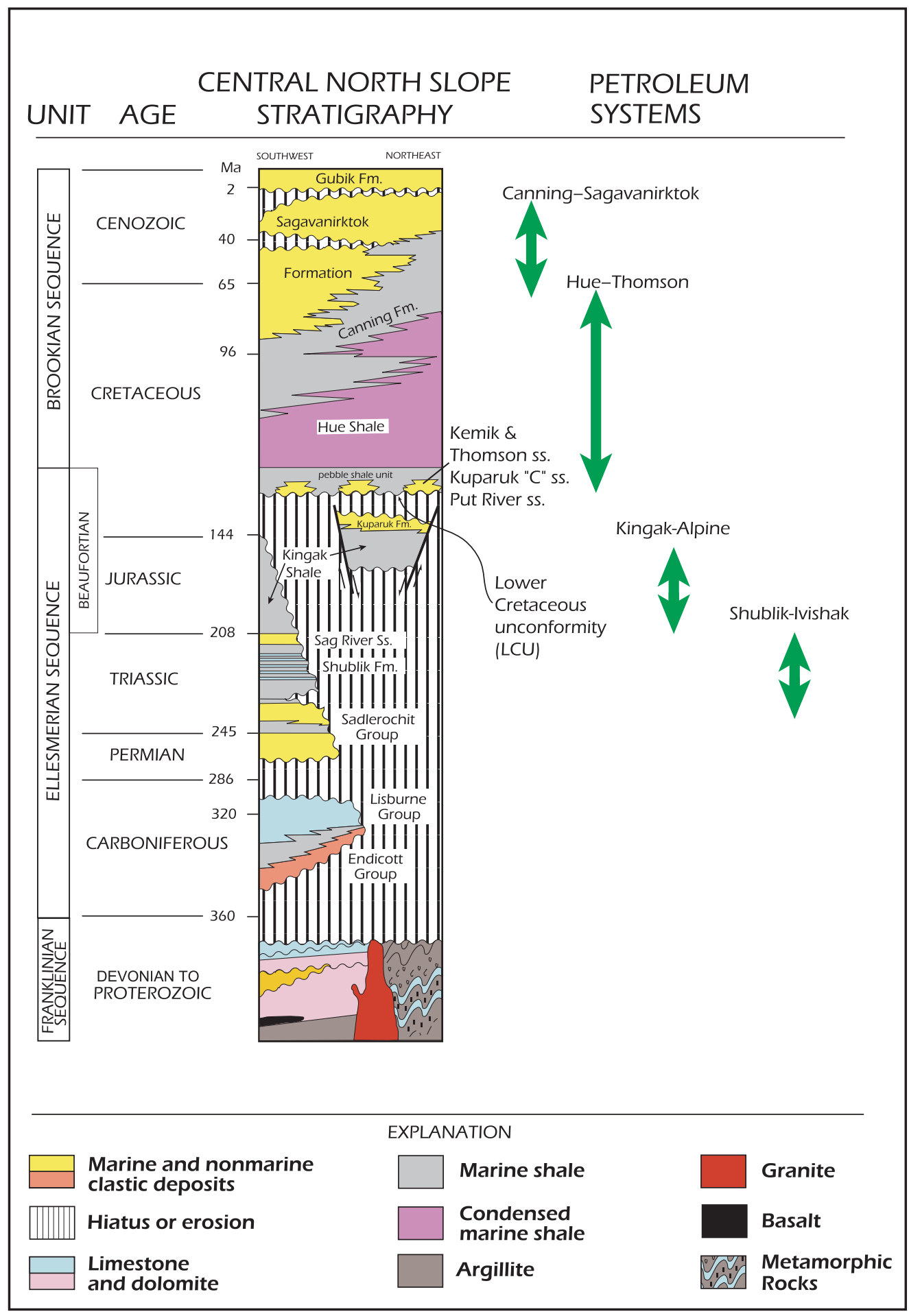

Figure 2. Stratigraphic column for the Central North Slope, Alaska. Reservoirs for the KemikThomson Play are the Kemik Sandstone and the Thomson sandstone, both deposited on the Lower Cretaceous unconformity (LCU). The Kuparuk "C" sandstone and the Put River Sandstone occur west of the play area. Four petroleum systems defined by Magoon and others (2003) in this part of the Alaskan North Slope were combined into one composite petroleum system for this assessment. 
With uplift in the Early Cretaceous came widespread erosion of the Ellesmerian sedimentary section, beginning with the Kingak Shale and extending down to the Lisburne Group and to Franklinian-age basement in some areas (fig. 2) such as on the crest of the Mikkelsen High (fig. 1). Axial metamorphism within the uplifted area resulted in a tensional regime, which caused partial collapse of the axial part of the Barrow Arch, and the formation of a wide zone of horst and graben structures that trend in the same northwest-southeast direction as the arch (Carman and Hardwick, 1983; Hubbard and others, 1987). The horsts were local sources of sediment, primarily eroded Ellesmerian and pre-Carboniferous strata, and the grabens and half-grabens were sediment traps. The sediments that accumulated in these structures were considered to be in a sequence termed the "Barrovian" by Carmen and Hardwick (1983; after the Barrow Arch), and the "Kup River" sequence by Noonan (1987), rather than being included with the underlying Ellesmerian sequence. Studies of similar-age, rift-related rocks in the offshore resulted in the naming of the Beaufortian sequence. Subaerial erosion resulted in a system of incised valleys or drainages along the flanks of the Barrow Arch (and its easterly extension, the Mikkelsen High). As rifting progressed to crustal breakup and sea-floor spreading, the uplifted area subsided, and a widespread transgression occurred across the Barrow Arch. Parts of the Kuparuk "C" sandstone and the Kemik Sandstone and Thomson sandstone were deposited during this transgressive event. The Lower Cretaceous Pebble Shale unit was deposited at the culmination of this transgression. These rift-related sediments were then onlapped from the southwest by prograding units of the Brookian sequence that resulted from structural movements related to the Brooks Range orogen in the south.

Progressive northward erosion of the LCU is illustrated by the subcrop map on the LCU (fig. 3). As erosion progressed, older units were exposed from south to north toward the Mikkelsen High, at the crest of which Franklinian-age basement rocks were also exposed during development of the LCU. This pattern of erosion is critical for the KemikThomson Play, because sediment derived from the Franklinian-age rocks, Kekiktuk Conglomerate of the Endicott Group, and rocks of the Lisburne Group and Sadlerochit Group (fig. 2) might have formed coarse-grained reservoirs in the play.

\section{Triassic-Tertiary Composite Petroleum System}

Six petroleum systems were previously defined on the Alaskan North Slope-in ascending stratigraphic order the Kuna-Lisburne, Shublik-Ivishak, Kingak-Alpine, GRZNanushuk, Hue-Thomson, and Canning-Sagavanirktok petroleum systems (Magoon and others, 2003). The ShublikIvishak, Kingak-Alpine, Hue-Thomson (including the pebble shale unit), and Canning-Sagavanirktok petroleum systems might have contributed petroleum to Kemik and Thomson reservoirs within the Kemik-Thomson Play of the Central North Slope area (Magoon and others, 1998; 2003). In our assessment of undiscovered resources in this play, we combined all of these systems into one-the Triassic-Tertiary Composite Petroleum System, as explained herein.

Thermal maturity data show that source rocks in the Shublik, Kingak, Hue, and pebble shale unit are thermally mature for oil throughout the Kemik-Thomson Play area (Magoon and others, 2003), but are thermally mature for gas in the southern part (figs. 4, 5). Modeling has shown that generation and migration of petroleum possibly occurred between 80 and $35 \mathrm{Ma}$ in these source rocks in the central part of the North Slope (Magoon and others, 2003). Source-rock facies of the Canning Formation (fig. 2) offshore from the play area reached maturity from $10 \mathrm{Ma}$ to the present, and petroleum might have migrated onto the Mikkelsen High.

Of the four major source rocks considered in the KemikThomson Play, the most likely sources for significant volumes of petroleum appear to be mudstones within the Lower Cretaceous Hue Shale and pebble shale unit (Magoon and others, 2003). These strata lie immediately above the Kemik Sandstone and Thomson sandstone, and the Hue Shale is thermally mature over much of the play area (figs. 6,7). We interpret the source rocks in what were defined by Magoon and others (2003) as the Kuna-Lisburne Petroleum System and the GRZNanushuk Petroleum System as not having contributed much petroleum to this play because of the location of the mature facies of the source rocks and the migration distances required to reach reservoirs.

Petroleum generated from source rocks in the ShublikIvishak, Kingak-Alpine, and Hue-Thomson Petroleum Systems of Magoon and others (2003) is postulated to have migrated up the structural dip into Kemik Sandstone and Thomson sandstone reservoirs along the crest and flanks of the Mikkelsen High (fig. 1). A strong possibility that mixing of petroleum occurred is indicated by analysis of oil samples and the similar pathways the petroleum would have followed from each of these sources. For example, several of the samples used to define the Hue-Thomson Petroleum System are cited as mixtures of petroleum from the Shublik, Kingak, and Hue stratigraphic intervals, or from the Hue and Shublik (Magoon and others, 2003). The Canning-Sagavanirktok Petroleum System of Magoon and others (2003) occurs offshore, and petroleum from mature Canning Formation source rocks might have migrated updip from the north to the south into Thomson reservoirs along the crest of the Mikkelsen High (fig. 1).

Because of potential mixing from different source-rock units, we defined the Triassic-Tertiary Composite Petroleum System on the basis that multiple sources might have contributed to petroleum accumulations in reservoirs of the KemikThomson Play. The boundary of this composite petroleum system is not known with certainty, but is defined as not only including the Kemik-Thomson Play of the Central North Slope but also the Kemik Play and the Thomson Play of the ANWR 1002 area (fig. 8) that were assessed in 1998 (Schenk and Houseknecht, 1999 a, b, c). The westward extent of the composite petroleum system has not been determined. 


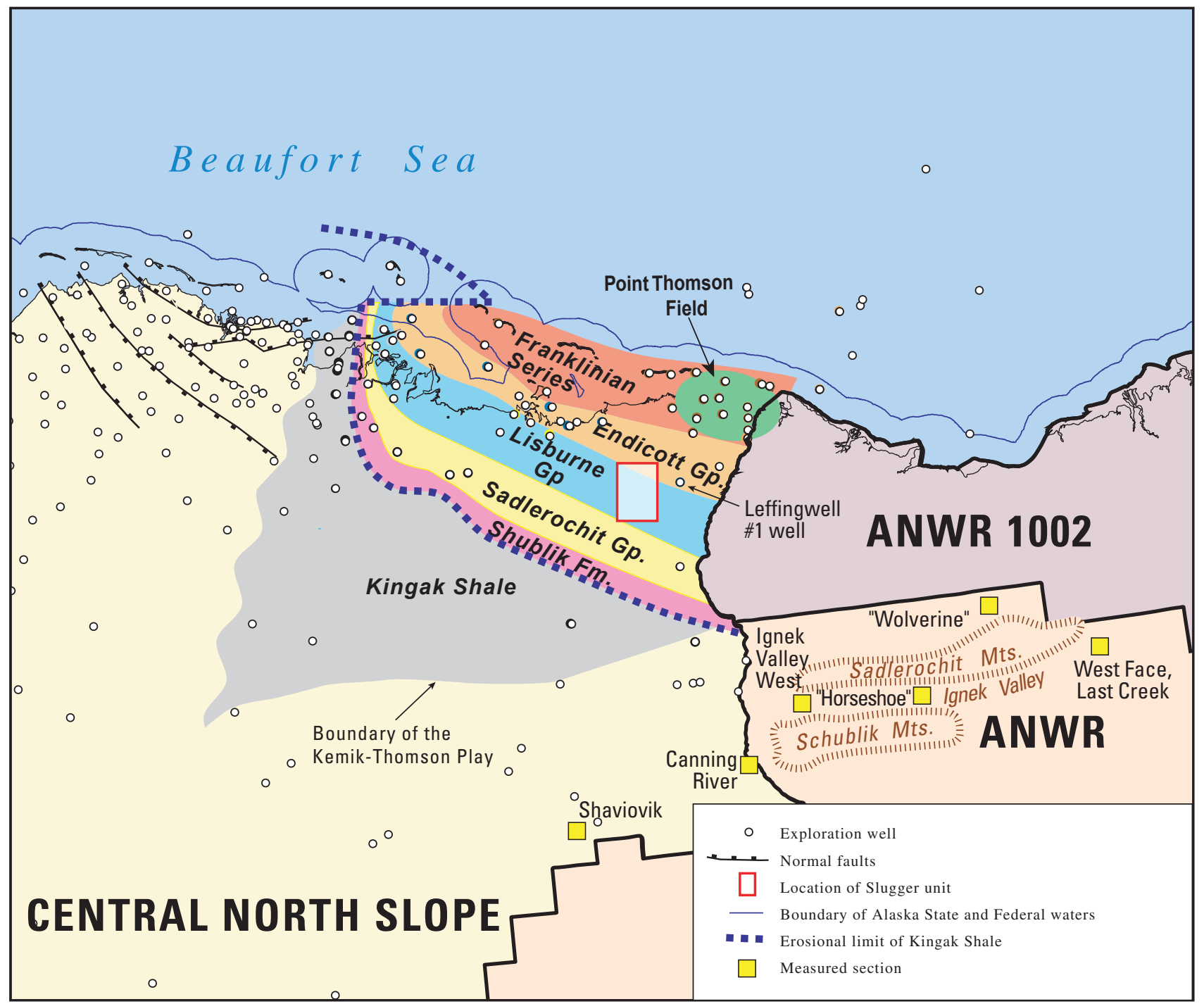

Figure 3. Map showing the distribution of rocks that subcrop the Lower Cretaceous unconformity (LCU) in the KemikThomson Play area. The map pattern illustrates the progressive erosion by the LCU, exposing older rock units from south to north onto the Mikkelsen High. Point Thomson Field shown in green. Erosional northern limit of the Kingak Shale shown by dashed blue line. Red box is approximate location of the Kemik Sandstone Slugger Unit. ANWR, Arctic National Wildlife Refuge; ANWR 1002, 1002 area of the Arctic National Wildlife Refuge. 


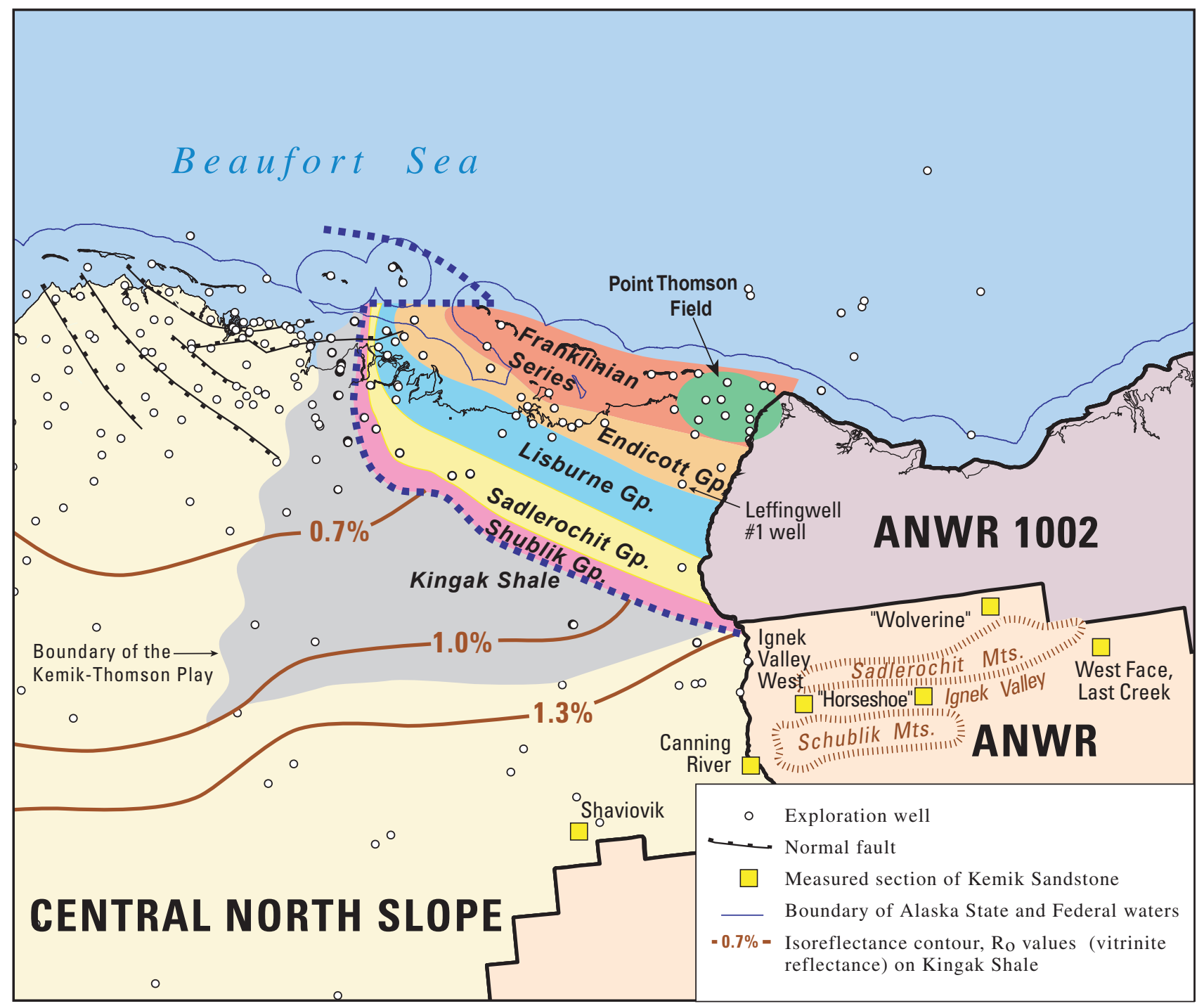

Figure 4. Thermal maturity of the Kingak Shale as shown by isoreflectance lines. Kingak Shale where present is thermally mature for petroleum generation over much of the Kemik-Thomson Play area. Erosional northern limit of the Kingak Shale shown by dashed line. Point Thomson Field shown in green. ANWR, Arctic National Wildlife Refuge; ANWR 1002, 1002 area of the Arctic National Wildlife Refuge. 


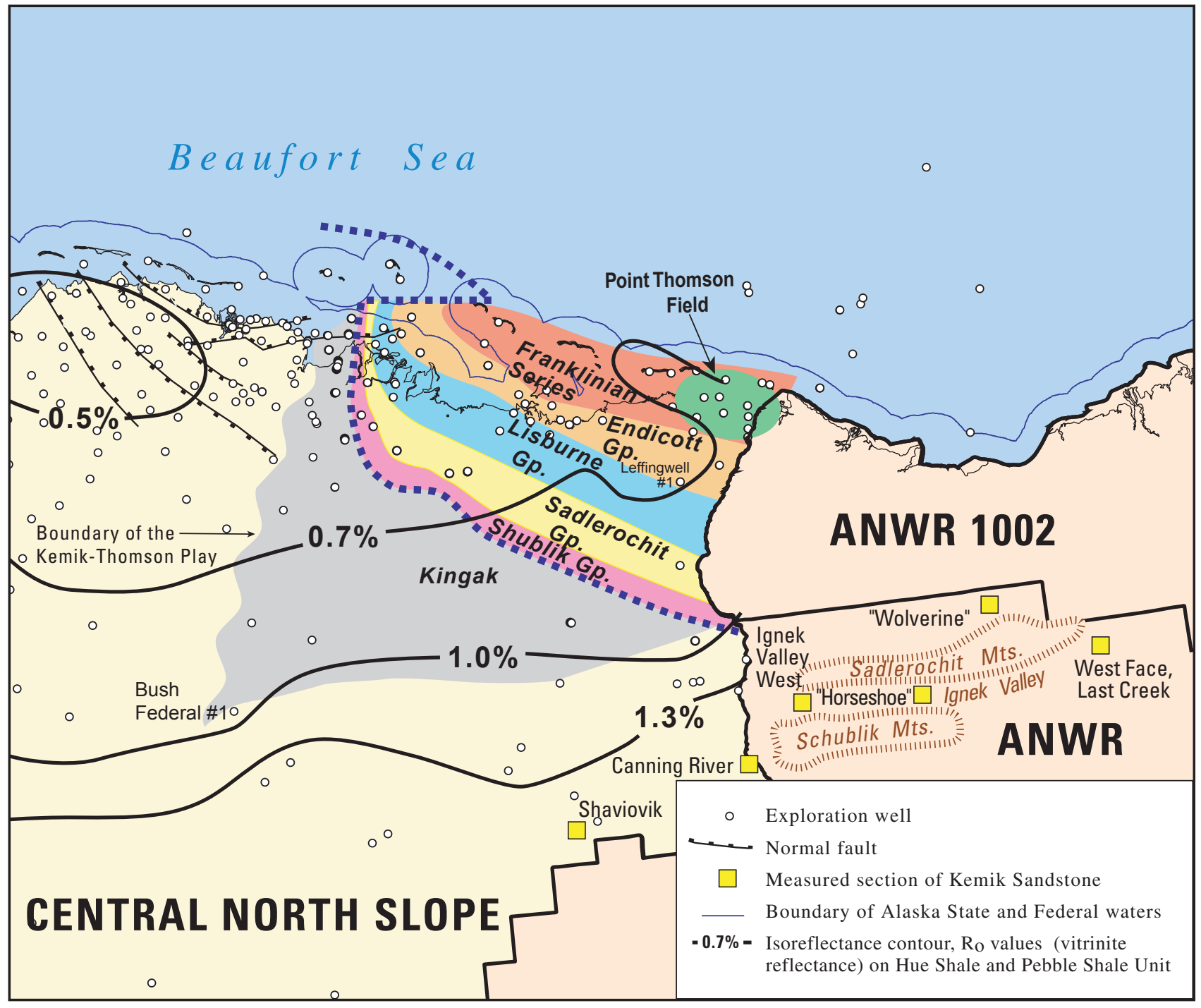

Figure 5. Thermal maturity of the Hue Shale (and pebble shale unit) as shown by isoreflectance lines. These source rocks are thermally mature for petroleum across the Kemik-Thomson Play area. Erosional northern limit of the Kingak Shale shown by dashed blue line. Point Thomson Field shown in green. ANWR, Arctic National Wildlife Refuge; ANWR 1002 , 1002 area of the Arctic National Wildlife Refuge. 


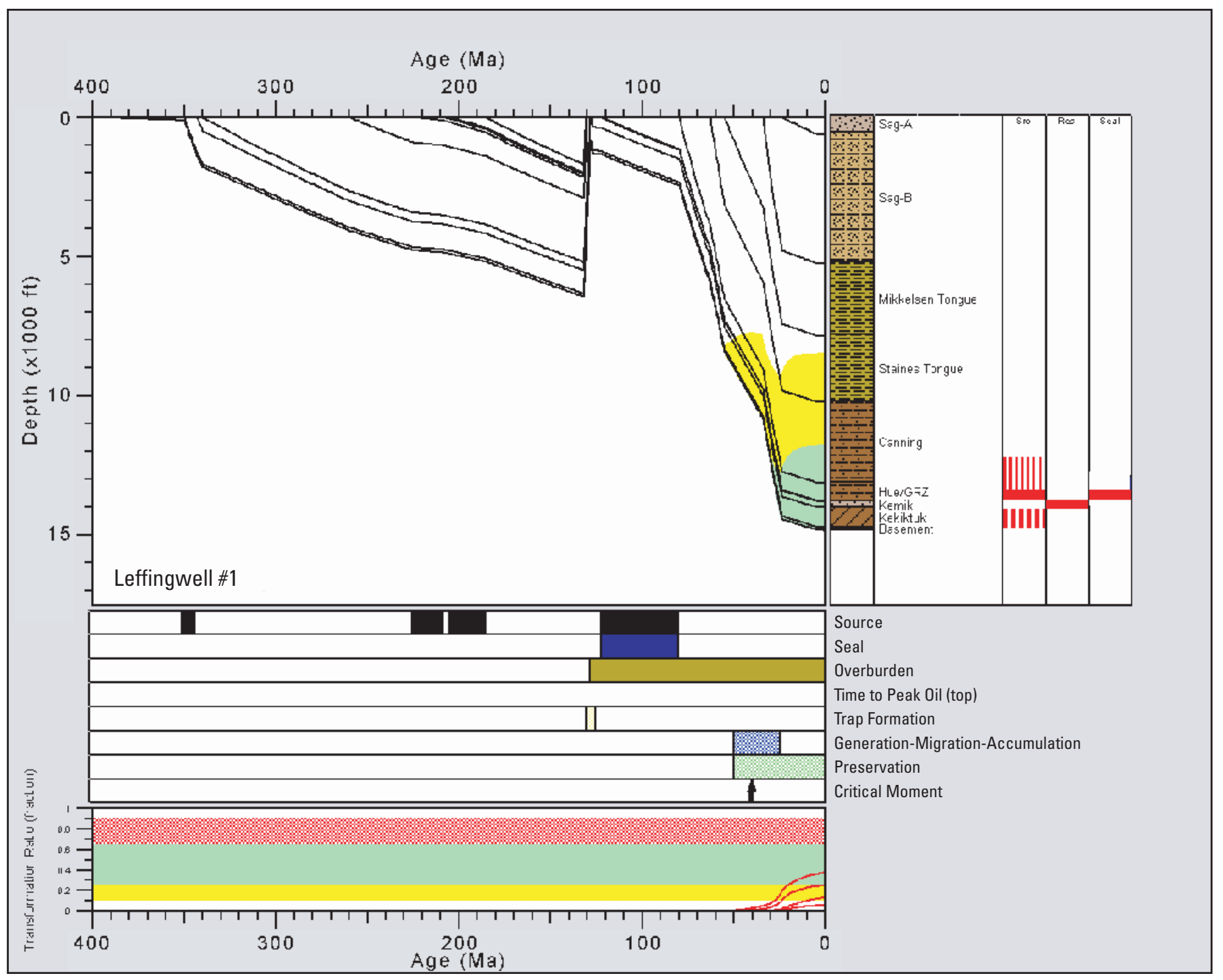

Figure 6. Burial-history plot of stratigraphic units in the Leffingwell \#1 well. The Hue Shale is thermally mature for oil in this burial history model. Location of well shown in figure 5. 


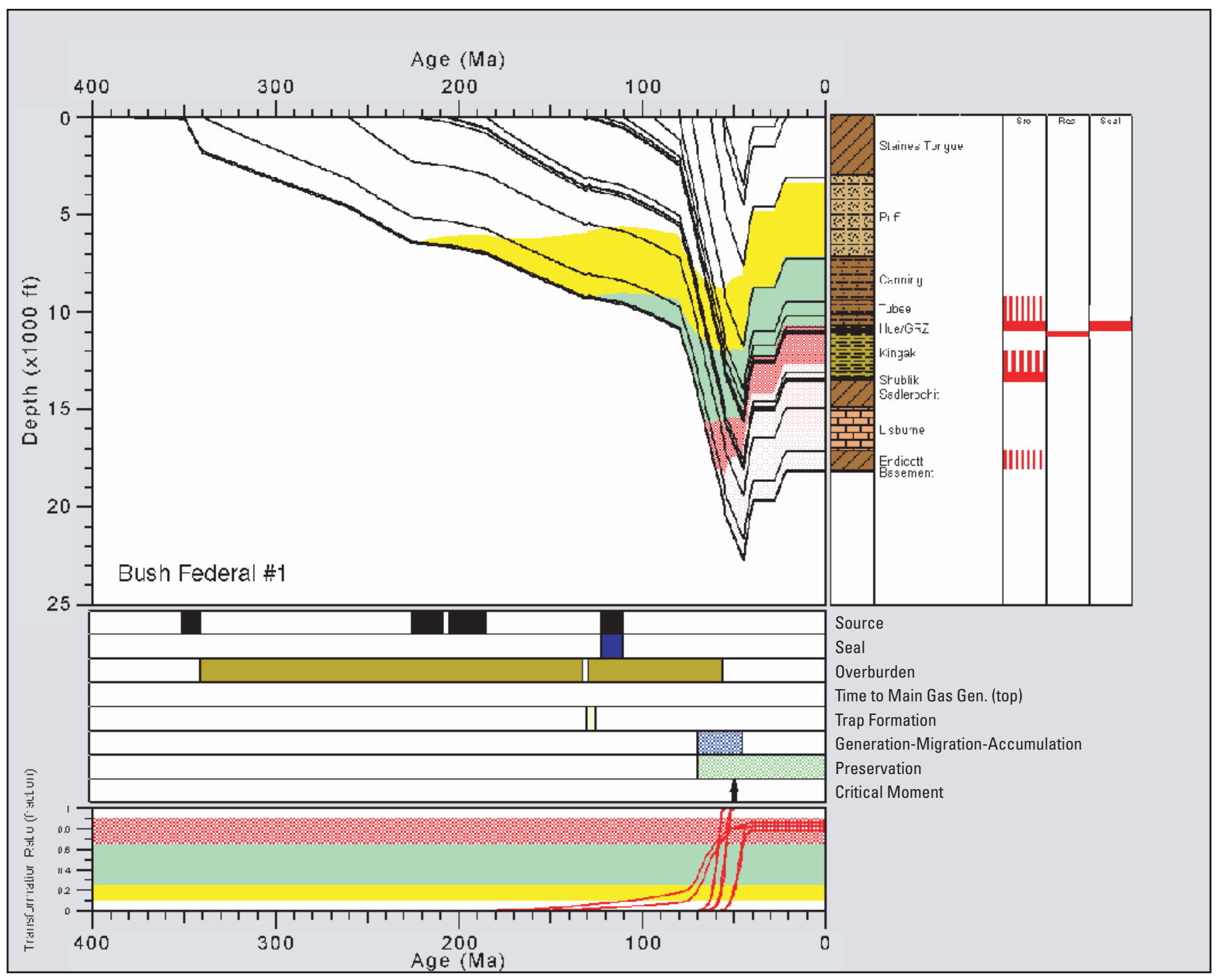

Figure 7. Burial-history plot of stratigraphic units in the Bush Federal \#1 well immediately south of the Kemik-Thomson play area. The Hue Shale is thermally mature for gas in this burial-history model. Location of well shown in figure 5. 


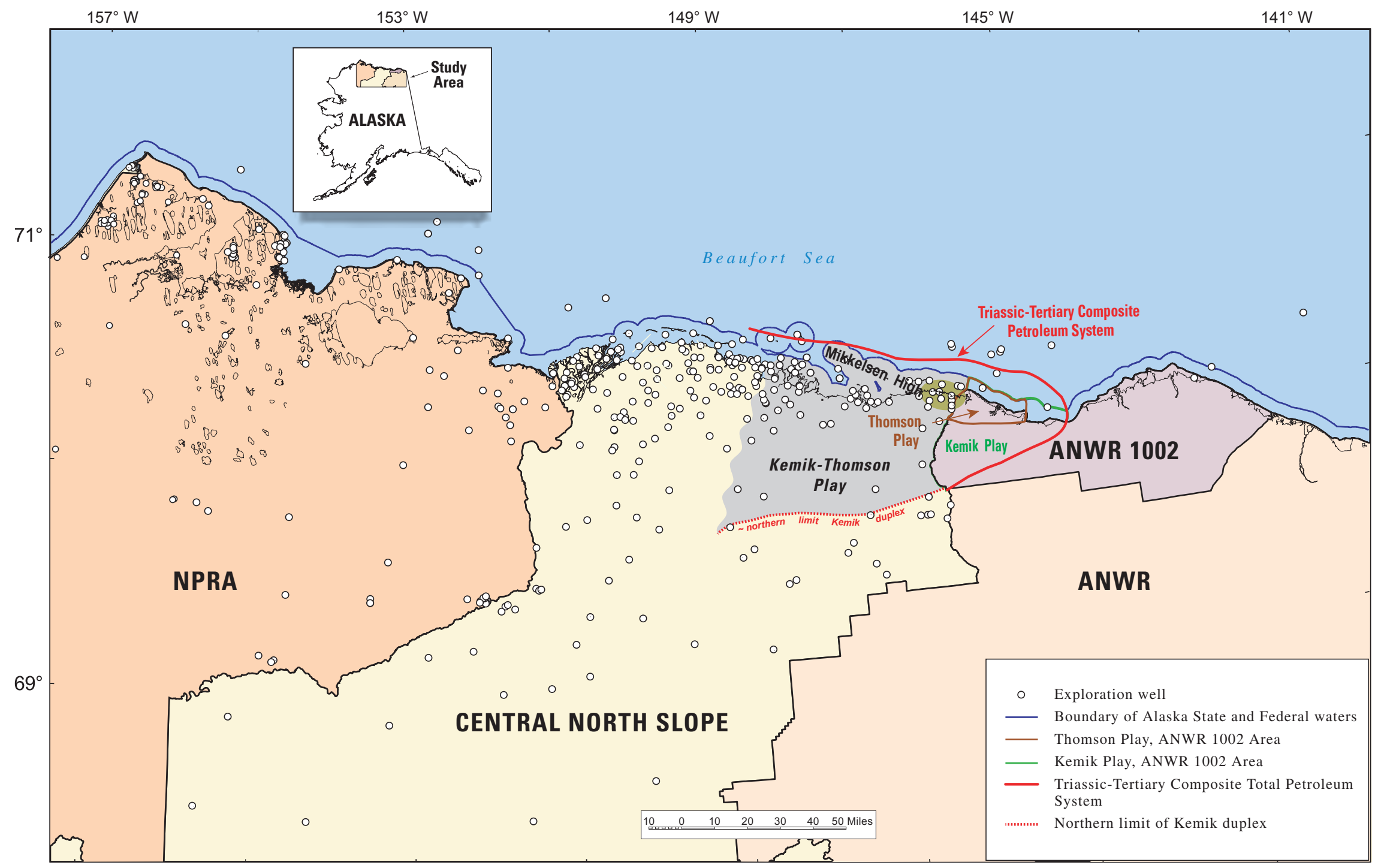

Figure 8. Map showing postulated extent of the Triassic-Tertiary Composite Petroleum System in the study area. The Kemik-Thomson Play (shown in gray) of the Central North Slope is included within this composite petroleum system, as are the Kemik Play and Thomson Play assessed to the east in the ANWR 1002 Area (Schenk and Houseknecht, 1999 a, b). Point Thomson Field shown in green. NPR-A, National Petroleum Reserve-Alaska; ANWR, Arctic National Wildlife Refuge; ANWR 1002, 1002 area of the Arctic National Wildlife Refuge. 


\section{Kemik Sandstone and Thomson Sandstone}

The Thomson sandstone is known only from wells drilled in the Point Thomson Field, and the term is restricted to that local area. The Kemik Sandstone is known from exposures in ANWR and in the Central North Slope area, and from several wells in the latter area that have penetrated the KemikThomson interval (fig. 1). The following sections describe what is known of the detrital composition, reservoir quality, and sedimentology of these two units.

\section{Detrital Composition}

The Kemik Sandstone has historically been differentiated from the Thomson sandstone on the basis of detrital composition. The Kemik Sandstone is generally a very fine to fine grained lithic arenite to quartz arenite, with varying percentages of chert and metamorphics as lithic grains (Reifenstuhl, 1995). The Thomson sandstone, in contrast, is characterized by a large percentage of carbonate lithic grains (Gautier, 1987), and is classified as a carbonate-lithic arenite (Reifenstuhl, 1995). The compositional differences are related to provenance; the Kemik Sandstone is interpreted most likely to have been sourced by siliciclastic rocks of the Permian-Triassic Sadlerochit Group (mainly the Ivishak Formation) and chert of the Carboniferous Lisburne Group, whereas the Thomson sandstone was most likely sourced by Franklinian-age carbonates and possibly by the Lisburne Group on the Mikkelsen High.

For our assessment, a more general definition of the Kemik Sandstone was applied using the subcrop map of the LCU (fig. 3). The Thomson terminology in this study is restricted to the area of the Point Thomson Field (fig. 1) and along the crest of the Mikkelsen High, but the Kemik Sandstone was expanded to include any coarse-grained detritus deposited on the LCU, regardless of composition, that occurs in the play area away from the immediate vicinity of Point Thomson Field. For example, if erosion of Lisburne Group or Kekiktuk Conglomerate of the Endicott Group led to the accumulation of coarse-grained sediment that was concentrated on the LCU, the term Kemik Sandstone was applied to that deposit. The distribution of rock underlying the LCU (fig. 3) illustrates that the Thomson terminology applies to the area underlain by Franklinian-age rocks, which are mainly carbonates, whereas coarse-grained Kemik facies are potentially developed from erosion of Endicott Group, Lisburne Group, and Sadlerochit Group rocks, which range from carbonate to siliciclastic in composition. This informal definition expands the use of Kemik Sandstone from a strictly siliciclastic composition.

Samples from the Thomson sandstone in the Point Thomson Field area illustrate the types of compositions and textures that we believe to be representative of both the undiscovered Kemik Sandstone and Thomson sandstone reservoirs in the Kemik-Thomson Play (fig. 9). The key point is that coarsegrained facies of the Kemik Sandstone and Thomson sandstone that are preserved on the LCU (fig. 2) must retain adequate porosity, either primary or secondary, to contain the volume of petroleum required to form the minimum accumulation size (5 million barrels of oil, MMBO) that was considered for this assessment.

\section{Reservoir Quality}

Most of the information on reservoir quality of the Kemik Sandstone comes from outcrop samples, which generally exhibit low porosities (range 0.8 to 14.1 percent, averaging 5.3 percent; Knock, 1987a, b; Reifenstuhl, 1995) and low permeabilities (range 0.00012 to $0.0157 \mathrm{mD}$ ). Porosity in the few subsurface samples analyzed ranged from 3.9 to 8.4 percent, with an average of 6.2 percent (Reifenstuhl, 1995). Slightly higher porosity values were reported by Bird and others (1987), with porosities ranging from 3 to 10 percent, and averaging 8 percent. All of these samples, however, are essentially from the very fine- to fine-grained sandstones of the Kemik that were not considered to be potential conventional reservoirs in this assessment. Kemik sandstones in the subsurface might be lowpermeability unconventional reservoirs, but these reservoirs were not considered in this assessment.

The Thomson sandstone contains a conglomerate facies and a sandstone facies. The sandstones are very fine to fine grained and well sorted, consisting of detrital dolomite clasts with minor quartz and argillaceous rock fragments. The conglomerate facies consists of boulder- to pebble-size clasts of coarsely crystalline dolomite. Although data are limited and appear to be mainly from the conglomerate facies, the Thomson sandstone reportedly has good to excellent reservoir properties, including porosity as high as 25 percent (average 16 percent), and permeability as much as a darcy or more (Bird and others, 1987; Gautier, 1987).

Examination of several hundred core-chip samples (at the Geologic Materials Center, Eagle River, Alaska) from wells in the Point Thomson Field has shown that visual porosity estimates of the conglomerate facies commonly are 12 percent or less, but with a few samples estimated as high as 25 percent. These samples comprise granule- to pebble-sized, rounded to subrounded carbonate clasts that exhibit poor to fair sorting. The matrix is typically fine-grained carbonate cement that commonly does not completely fill the pores, thus leaving interconnections between them. There is also some secondary porosity as evidenced by the remains of cement rinds that can be seen around partially dissolved carbonate framework grains. The conglomerate facies has not undergone significant compaction as shown by the slight dissolution at framework grain point-contacts. Many samples from the Exxon Point Thomson \#1 well in the Point Thomson Field exhibited a bitumen like residue in the pore spaces. Intercalated with the conglomerates are fine-grained carbonate-lithic sandstones, and quartz and lithic Kemik-like sandstones. Visual porosity in most of these sandstones is less than 10 percent, and a few samples had visual porosity estimated to be about 15 percent. Sorting is typically poor to fair, and the grains are mainly subrounded. Many samples have significant percentages of metamorphic lithic fragments. Several of the sandstones in thin section exhibited replacement of quartz by carbonate. 


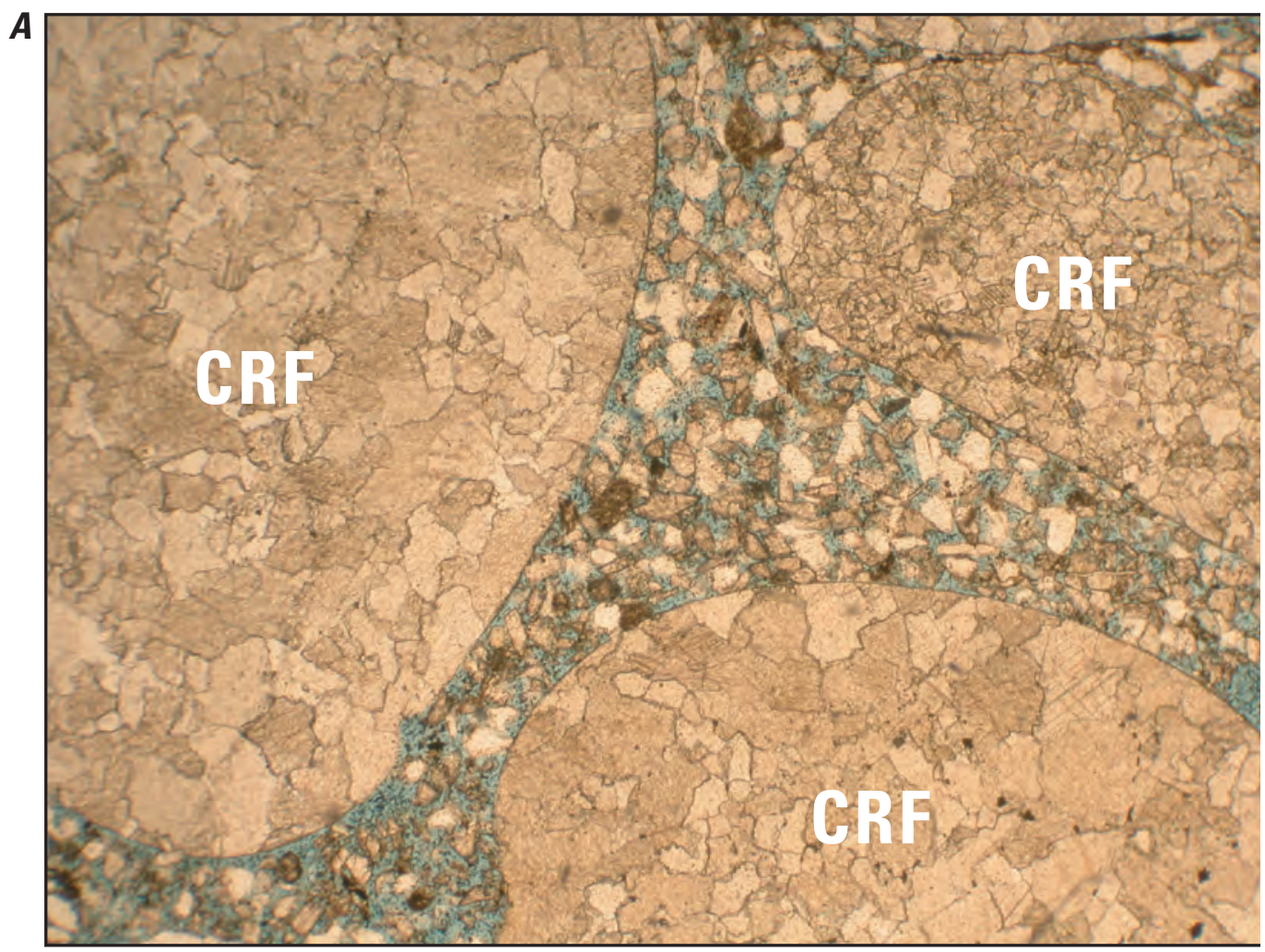

B

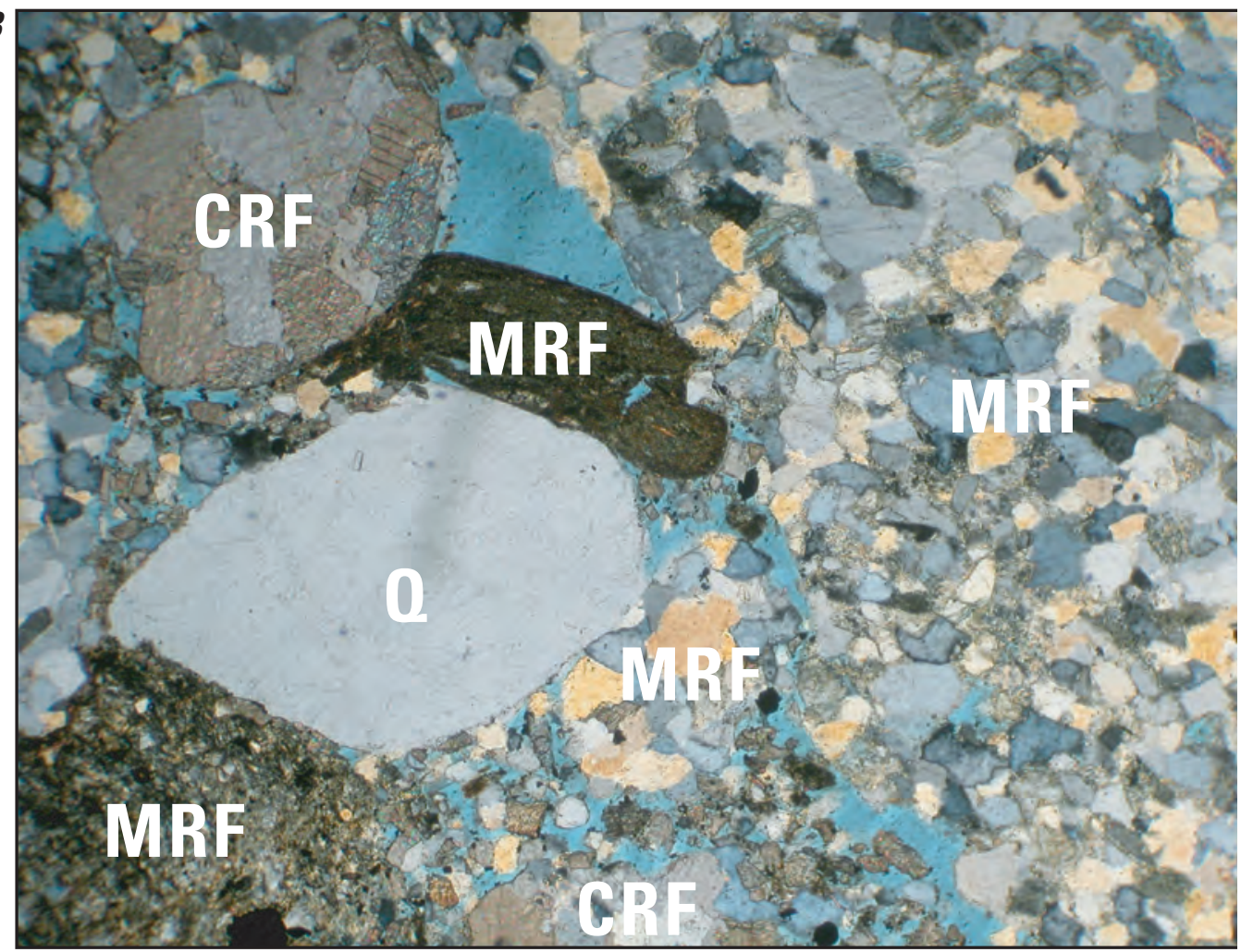

Figure 9. Selected photomicrographs of the Thomson sandstone from Point Thomson Field. A. Large-diameter carbonate rock fragments (CFR) are common in the Thomson sandstone. Blue represents porosity. Sample from Point Thomson \#3 well, depth 13,678 ft. Bottom dimension of photograph is $0.3 \mathrm{~mm}$. B. Other framework grains include quartz (0) and metamorphic rock fragments (MFR). Sample from Point Thomson \#3 well, depth 13,786 ft. Bottom dimension of photograph is $0.3 \mathrm{~mm}$. 
In summary, the very fine and fine grained sandstones of the Kemik Sandstone do not form adequate conventional reservoirs in this play, whereas the Thomson sandstone, with its coarser grain size and potential for secondary porosity appears to exhibit the best reservoir quality. The potential for Kemik Sandstone conventional reservoirs exists only where coarsegrained sands might have resulted from local erosion of various lithologies underlying the LCU, and where the sandstones might have been preserved in incised valleys on the LCU. However, this type of reservoir has not yet been observed in outcrop or encountered in wells that have penetrated the Kemik Sandstone.

\section{Sedimentology of the Kemik Sandstone}

A recent interpretation of the Kemik Sandstone places the various facies observed in outcrop into a sequence-stratigraphic context (fig. 10) (Schenk and Houseknecht, 2002). This interpretation expands upon several interpretations of outcrops of the Kemik Sandstone in the Sadlerochit Mountains, in the Ignek Valley of ANWR (fig. 3), and in the Central North Slope (Molenaar and others, 1987; Mull, 1987; Melvin, 1987; Knock, 1986; Reifenstuhl, 1995).

The Kemik Sandstone is best exposed in the Ignek Valley of ANWR (fig. 3), where the sandstone is sharp based, ranges from 30 to $100 \mathrm{ft}$ thick, and has been interpreted as a barrierisland sandstone (Mull, 1987; Reifenstuhl, 1995) or as a marine shelf sandstone (Knock, 1986, 1987a, b; Melvin, 1987; Molenaar and others, 1987). We agree with the interpretation that the Kemik Sandstone in outcrop represents a shallow marine sandstone based on vertical successions of sedimentary and biogenic structures. The sharp-based Kemik Sandstone exposed in and around Ignek Valley possibly formed 1) during transgression, where the sharp base represents a transgressive surface of erosion, or 2) during a base-level fall in early to late lowstand of sea level, in what has been called a forced regression (Posamentier and Morris, 2000). Exposures of thin (less than $20 \mathrm{ft}$ thick) Kemik Sandstone, such as the sandstones exposed at Shaviovik (fig. 3) are interpreted as thin, transgressive marine sandstones. Similar thin sandstones are interpreted from the upper part of the well log from the Leffingwell \#1 well. Where the Kemik Sandstone is thick (200-300 ft), as in the Leffingwell \#1 well, we interpret the Kemik Sandstone as a possible late lowstand to transgressive valley-fill deposit. The thick Kemik Sandstone in the Leffingwell \#1 well (fig. 5) could be one such late-lowstand to transgressive valley fill in the Kemik Sandstone (fig. 10). No valley-fill deposits have been observed in outcrops of the Kemik Sandstone.

The Kemik Sandstone in the Central North Slope and in ANWR is interpreted as representing a spectrum of marine and marginal-marine facies in a sequence stratigraphic context. The sharp-based marine Kemik Sandstone and the thin transgressive sandstones, although they form the bulk of the outcrop in the southern part of the play area, are considered not to have reservoir properties of sufficient quality to contain a conventional accumulation of minimum size. The facies of the Kemik that we believe to potentially have adequate reservoir properties for a conventional petroleum accumulation is the locally-sourced, coarse-grained valley-fill facies.

An example of such a potential reservoir might be the Kemik Sandstone within the so-called Slugger Unit (fig. 11), in which seismic data illustrate dipping reflectors that are interpreted as the Lisburne Group or as the Kekiktuk Conglomerate exhibiting possible erosional topography associated with the LCU. In our interpretation, an incised valley formed by the unconformity is filled in with possible coarse-grained detritus sourced from the Lisburne Group or Kekiktuk Conglomerate, or both, and the potential Kemik Sandstone reservoirs are sealed by the pebble shale unit and possibly by the Hue Shale.

The sedimentary deposits in these valley fills can be complex, ranging from fluvial to marine (Van Wagoner and others, 1990; Dalrymple and others, 1994; Zaitlin and others, 1994), with the coarse-grained fluvial deposits constituting the main potential reservoirs in the Kemik-Thomson Play. Other facies might serve as reservoirs within incised valleys, including estuarine and marine sandstones. The reservoirs in the Point Thomson Field might represent the proximal, dominantly fluvial facies of the incised valleys on the Mikkelsen High (fig. 1).

\section{Sedimentology of the Thomson Sandstone}

The Thomson sandstone was deposited on the LCU along the flanks and crest of the Mikkelsen High, and the Thomson terminology has generally been restricted to the immediate area of Point Thomson Field. The Thomson sandstone is known to contain significant quantities of petroleum, reportedly as much as 8 trillion cubic feet of gas and 450 million barrels of condensate in the Point Thomson Field (Bird and others, 1987, Alaska Department of Natural Resources, 2003). The stratigraphy of the Thomson sandstone is known only from the interpretation of several well logs in the Point Thomson Field, and its regional distribution is indeterminate. Well logs from the field show a blocky sandstone representing the Thomson interval immediately above the LCU, but the fact that it is not present in every well on the Mikkelsen High indicates its discontinuous nature (fig. 12). The blocky log character suggests a relatively uniform set of physical properties through the thickness of the sandstone, possibly representing a thick fluvial section. The Thomson sandstone could possibly be associated with stratigraphic traps, as the sands were deposited in incised valleys associated with the LCU on the Mikkelsen High.

Erosion leading to incised valleys on the Mikkelsen High might have produced channels with gradients descending off the flanks of the uplift, which is not an optimal situation for trapping petroleum. Petroleum migrating from downdip generative areas in the Hue Shale and other source rocks would presumably move up through these valley-fill sandstones, and possibly leak or be degraded before significant trapping occurred. However, bends in sinuous fluvial paleo-valleys might serve as petroleum traps. 


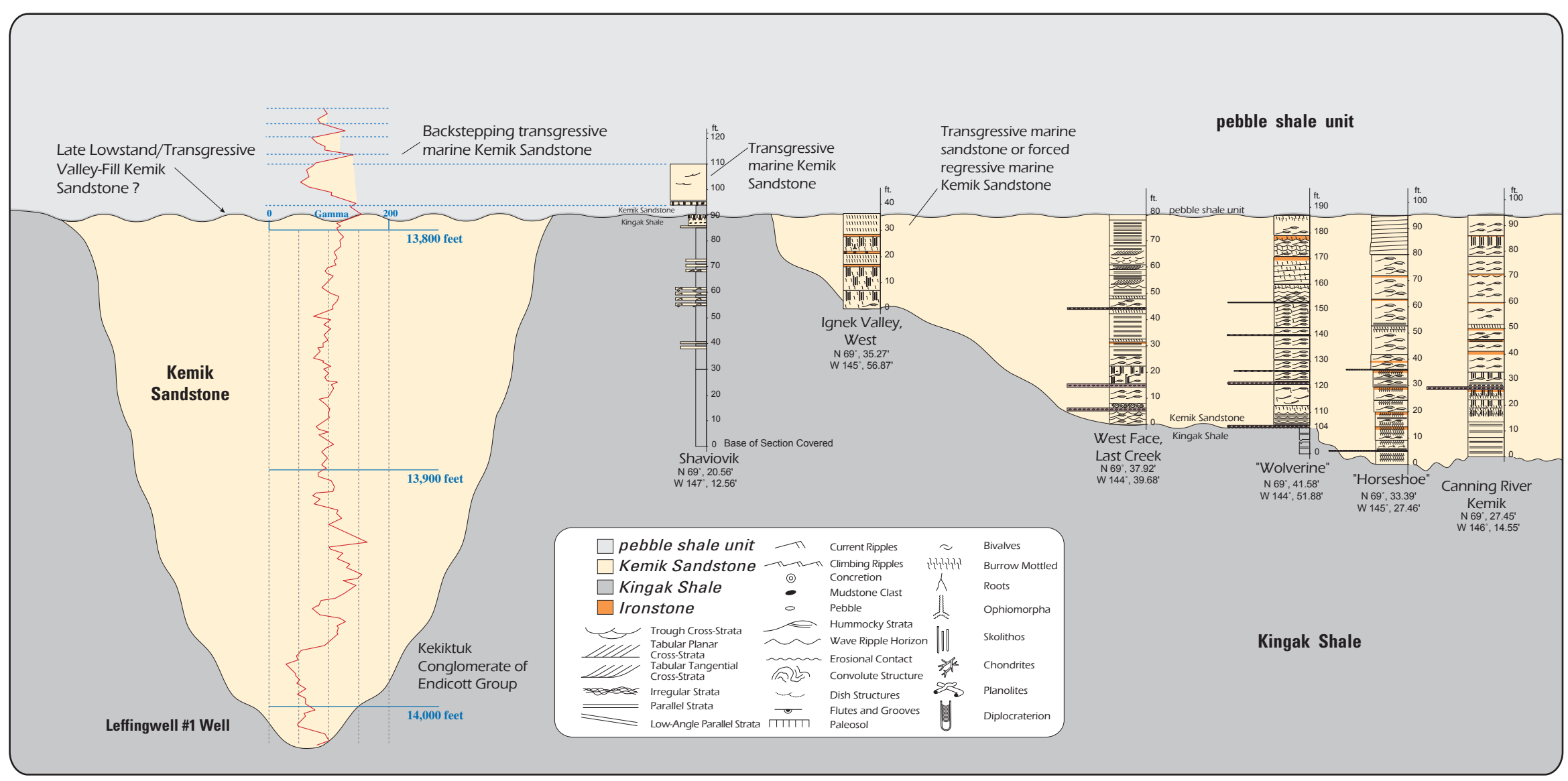

Figure 10. Cross section illustrating facies of selected measured sections of the Kemik Sandstone in a proposed sequence-stratigraphic context. Potential conventional reservoirs in the Kemik-Thomson Play are postulated to be coarse-grained facies of the Kemik Sandstone preserved in incised valleys. Location of measured sections of Kemik Sandstone shown in figure 3. Location of the Leffingwell \#1 well shown in figure 5. 


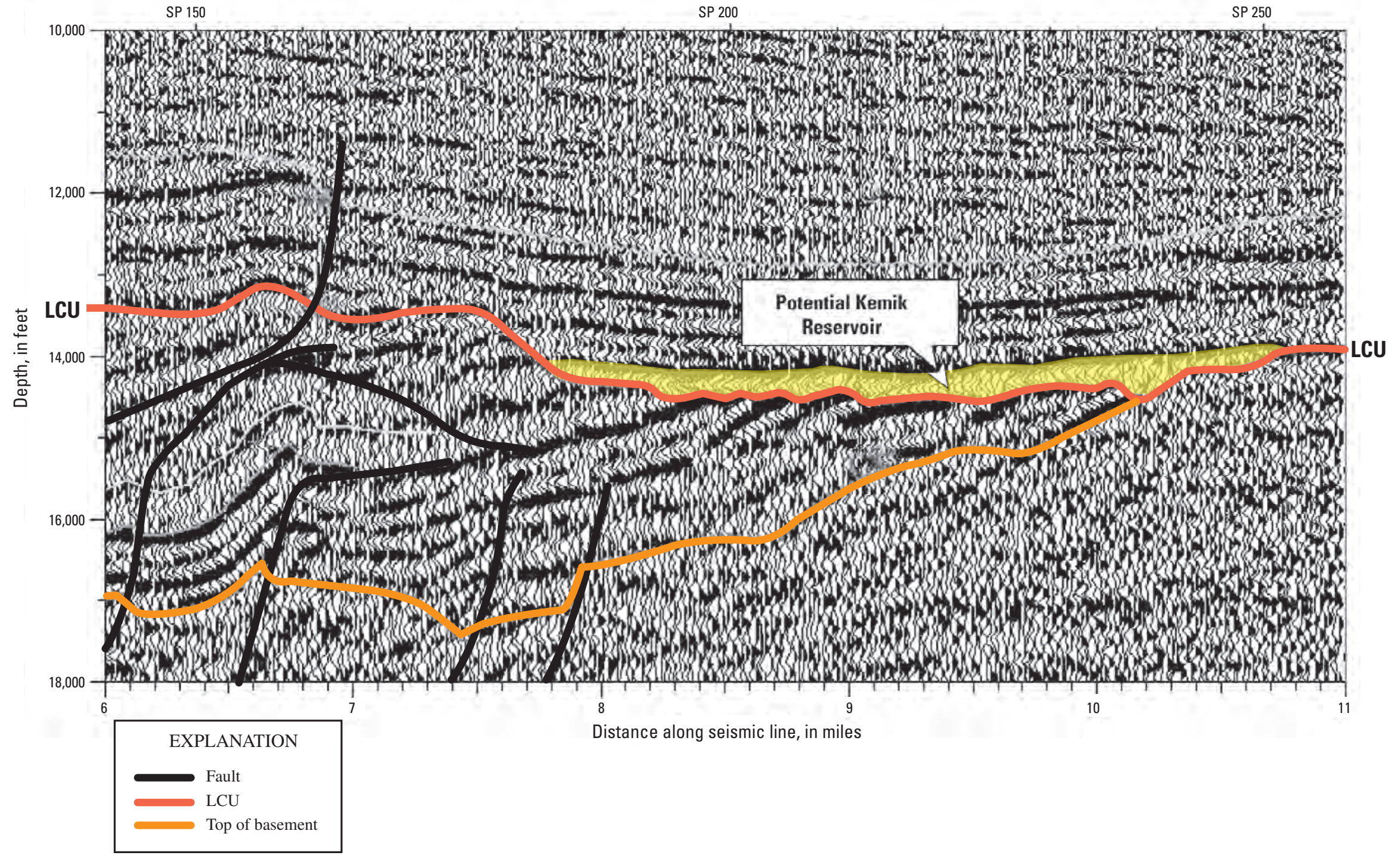

Figure 11. Interpreted seismic profile of possible Kemik Sandstone reservoir and trap in the so-called Slugger Unit of the Central North Slope, Alaska. Dipping reflectors above basement are interpreted to be siliciclastic units of the Kekiktuk Conglomerate or carbonates of the Lisburne Group; erosion on the Lower Cretaceous unconformity formed sites for the deposition of coarse-grained Kemik Sandstone resulting in potential reservoirs for conventional oil or gas. General location of the Slugger Unit shown in figure 3. Heavy red line is the LCU. 


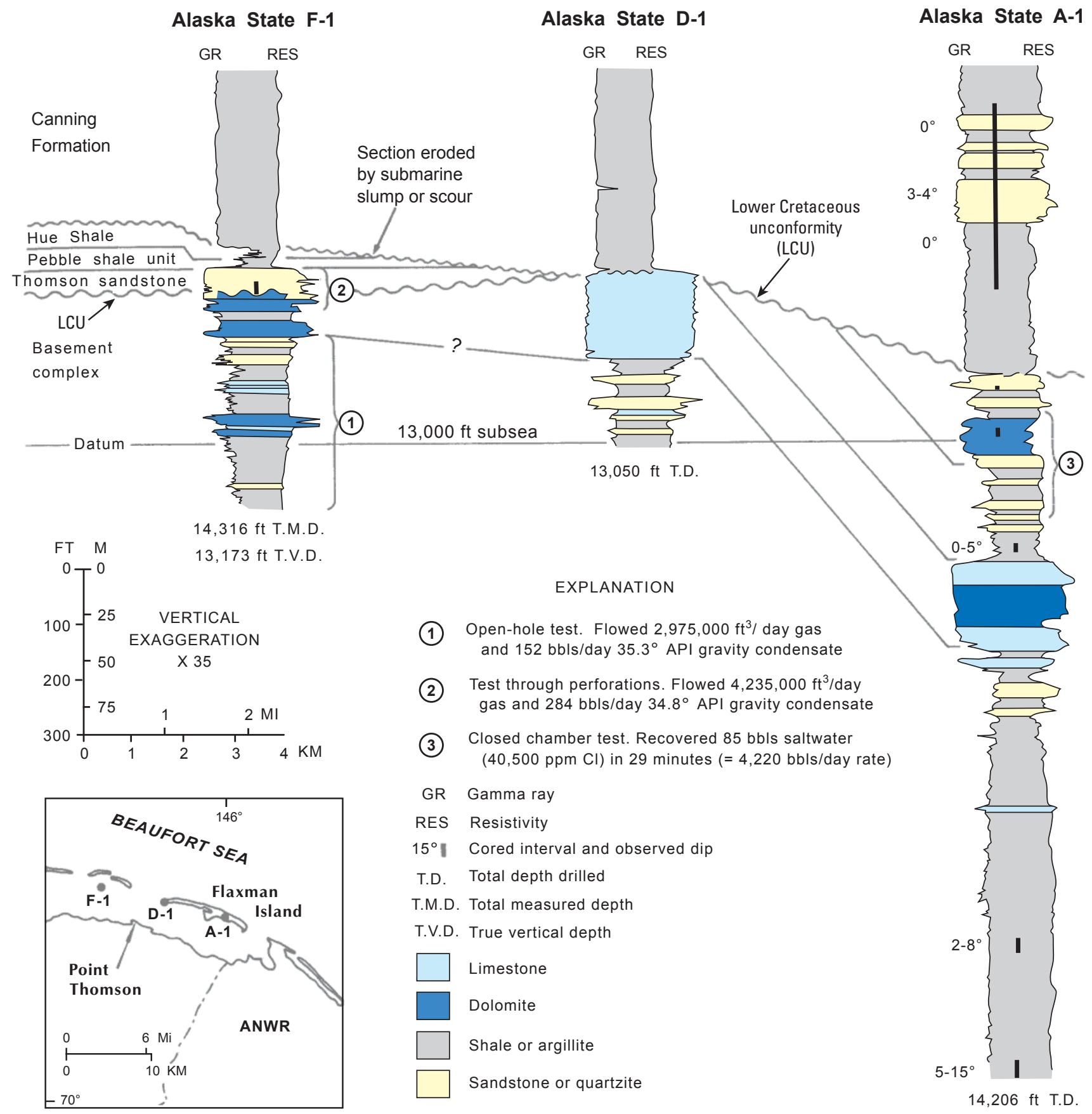

Figure 12. Borehole geophysical log cross section of the Thomson sandstone in Point Thomson Field. The Thomson sandstone occurs in incised valleys as a locally derived, coarse-grained sediment accumulation. Modified from Bird and others (1987). 
Coarse-grained clastics within incised valleys form petroleum reservoirs in many areas, such as in the Lower Cretaceous Muddy Sandstone of the Powder River Basin, Wyoming, which we used as a geologic analog for the KemikThomson Play (fig. 13). In this analog, an incised-valley system developed on an eroded surface of the Lower Cretaceous Thermopolis-Skull Creek Shale (Dolton and Fox, 1996) was filled during late lowstand and transgression with sandstones and minor conglomerates. The Muddy Sandstone reservoirs were then covered by the Upper Cretaceous Mowry Shale that serves not only as a top seal to the sandstone reservoirs but is also interpreted as the main source for petroleum.

The oil field-size distribution for the Muddy Sandstone in the Powder River Basin shows that a few large fields on the order of $100 \mathrm{MMBO}$ have been discovered, but most fields are smaller, generally less that about 15 MMBO. Using a minimum accumulation size of $5 \mathrm{MMBO}$ for our Kemik-Thomson Play, and applying the Muddy Sandstone analog, we estimate that about 30 accumulations might be possible in the KemikThomson incised-valley system with the largest accumulation in the range of $100 \mathrm{MMBO}$.

The Thomson sandstone might have also been deposited in a series of northwest-southeast-trending grabens that (1) formed on the flanks and crest of the Mikkelsen High during the extensional regime associated with rifting, and (2) served as sites for the accumulation of coarse-grained carbonate detritus shed from higher areas flanking them. With continued transgression, mudstones of the Hue Shale and pebble shale unit were deposited and covered the sandstones, serving both as a top seal and a petroleum source.

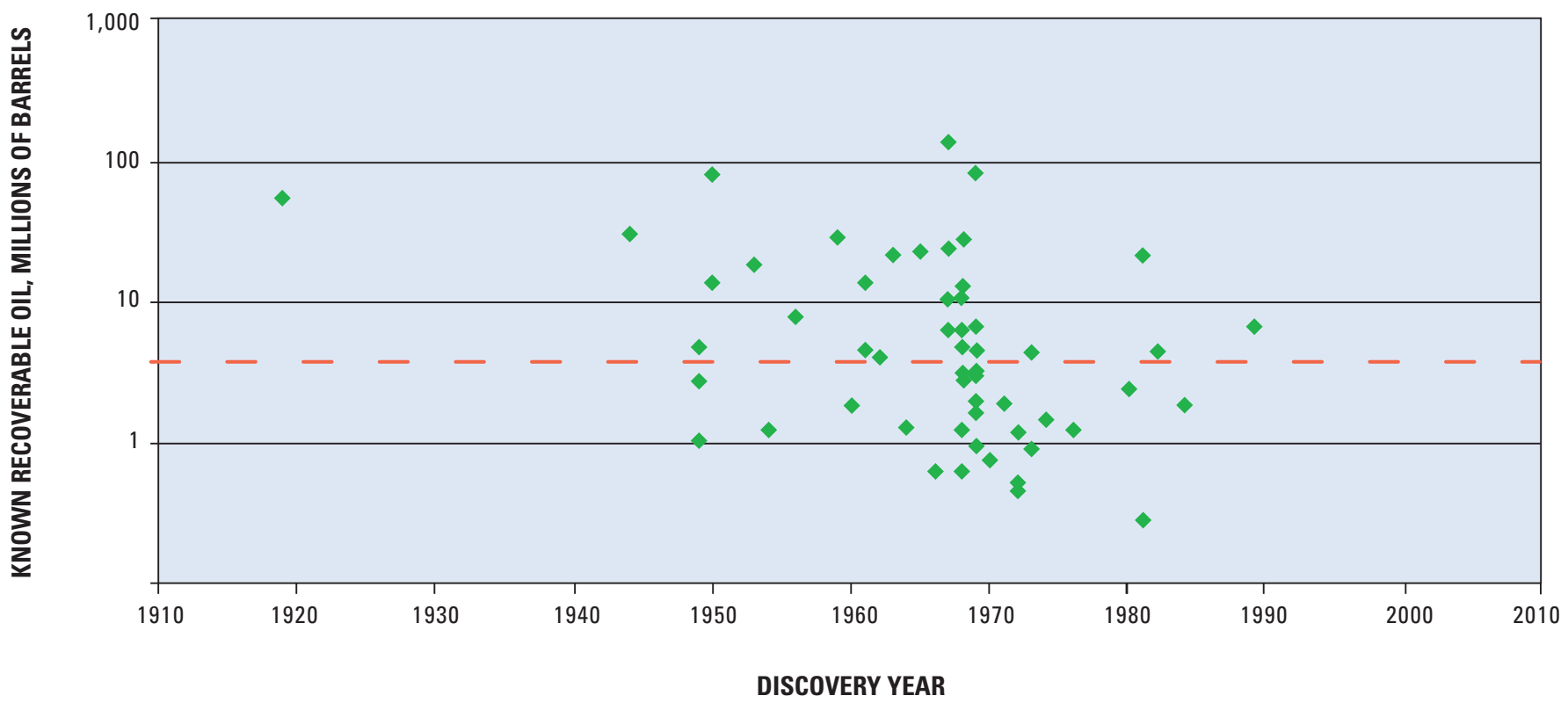

Figure 13. Plot of oil accumulation size relative to discovery year for the Lower Cretaceous Muddy Sandstone in the Powder River Basin, Wyoming, a possible geological analog for oil and gas accumulations in the Kemik-Thomson Play. Dashed red line approximates the minimum accumulation size (5 million barrels of oil) used in the assessment of the Kemik-Thomson Play. 


\section{Geologic Model for Assessment}

Based on the foregoing interpretation, our model for assessing undiscovered oil and gas resources in the KemikThomson Play consists of the following principal elements:

1. The Lower Cretaceous Kemik Sandstone and Thomson sandstone accumulated as coarse-grained deposits in paleo-valleys eroded into the various stratigraphic units underlying the Lower Cretaceous unconformity (LCU), including Franklinian-age carbonates, Carboniferous Endicott Group siliciclastics (including the Kekituk Conglomerate), Carboniferous Endicott Group carbonates, and Permian-Triassic Sadlerochit Group sandstones (fig. 2).

2. Locally derived detritus of either carbonate or clastic composition comprise the Kemik Sandstone and Thomson sandstone reservoirs.

3. Seals to the reservoirs were formed by mudstones of the Lower Cretaceous Hue Shale and pebble shale unit (fig. 2).

4. Petroleum was generated from several potential source rocks, including the Triassic Shublik Formation, Jurassic Kingak Formation, Lower Cretaceous Hue Shale and pebble shale unit, and possibly from organic-bearing mudstones of the Cretaceous-Tertiary Canning Formation, offshore to the north of the play area.

5. Migration of petroleum was updip from south to north toward the Mikkelsen High generally between 80 and $35 \mathrm{Ma}$, and possibly at about $10 \mathrm{Ma}$ from offshore rocks into Kemik Sandstone and Thomson sandstone reservoirs.

In the resource assessment process, each assessor is required to describe (1) the geologic attributes of a play (charge, traps/rock, timing) and to assign probabilities to each of these attributes that reflect the chance of there being one accumulation of minimum size (5 MMBO; 100 billion cubic feet of gas, BCFG); and (2) the geologic attributes of the various prospect parameters (including net reservoir thickness, area of structural closure, porosity, potential trap fill, water saturation, trap depth range, and number of prospects) generally used to calculate pore-volume characteristics of a potential prospect (see Appendix 1). The elements of the geologic model outlined above provide a general framework for detailed discussions of these various attributes (given in the following sections), as they pertain to the Kemik-Thomson Play and the TriassicTertiary Composite Petroleum System. A summary of geologic events and their timing is graphically presented in figure 14 .

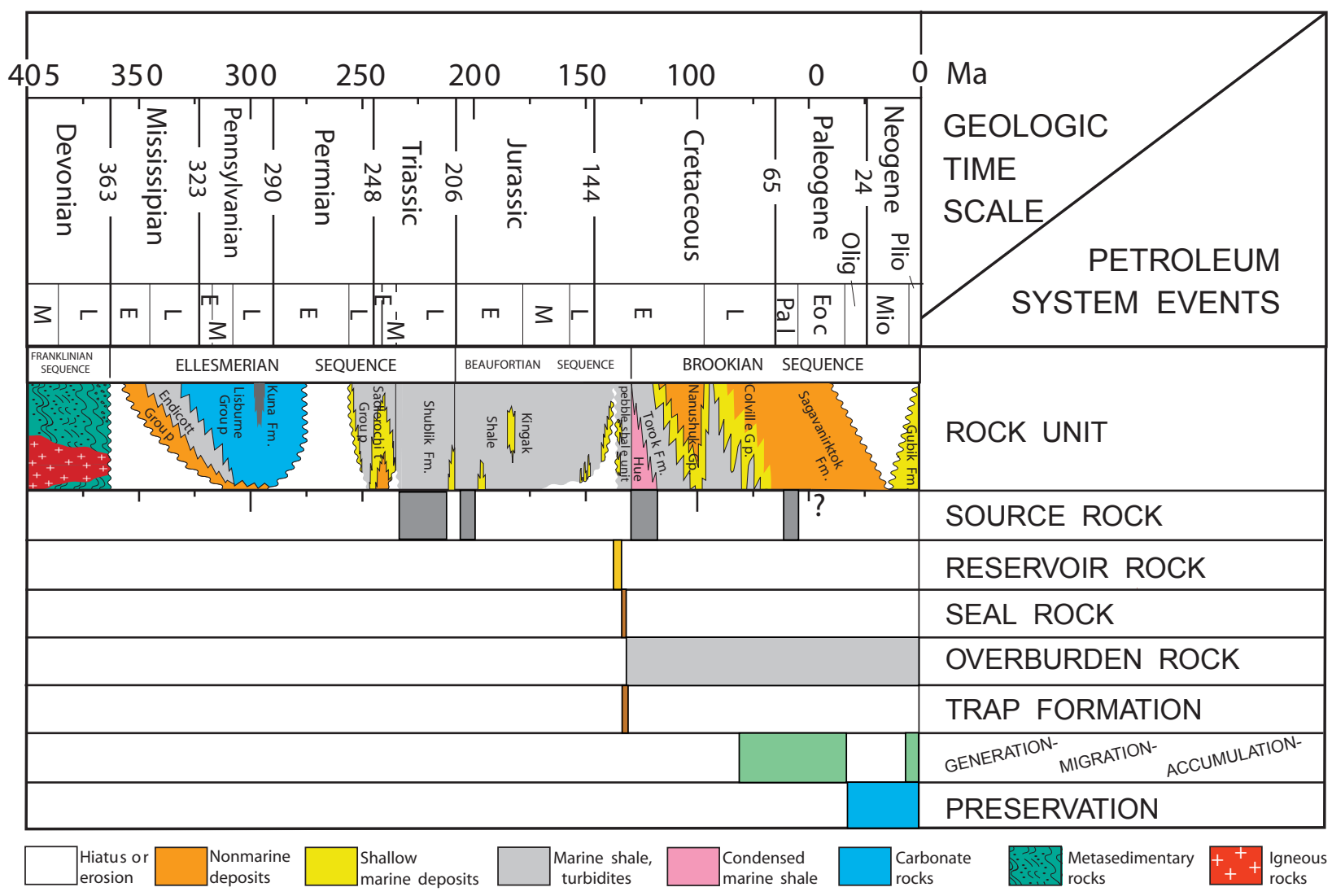

Figure 14. Events chart for the Triassic-Tertiary Composite Petroleum System summarizing the main elements of the geologic model used in the assessment of the Kemik-Thomson Play. In this model, generation and accumulation of petroleum from all potential source rocks occurred after formation of stratigraphic traps in the Kemik Sandstone and the Thomson sandstone. 


\section{Kemik-Thomson Play Attributes}

\section{Charge}

The main sources of hydrocarbons for reservoirs in the Kemik-Thomson Play are interpreted to be the Hue Shale, the pebble shale unit, and possibly the Kingak Shale (Magoon and others, 2003). Migration of petroleum from thermally mature facies of the Hue Shale and pebble shale unit would have been either down into underlying Kemik Sandstone reservoirs or laterally into such Kemik and Thomson reservoirs that lay updip along the flanks of the Mikkelsen High. Other possible source rocks include (1) the Triassic Shublik Formation and the Jurassic Kingak Formation, both of which are thermally mature for petroleum generation and are downdip from the postulated reservoirs in this play; and (2) organic-bearing mudstones of the Canning Formation offshore from the Mikkelson High, petroleum from which might have partially sourced reservoirs in the Point Thomson Field and its possible extension. Considerations of the thermal maturity and burial history of the Hue Shale and other source rocks, their maximum burial depths, and kerogen types suggest that 50 percent of the undiscovered petroleum in the Kemik-Thomson Play is probably oil. Charging of Thomson sandstone reservoirs would not require much migration distance because of the close proximity of source rocks. The occurrence of significant hydrocarbons in the Point Thomson Field and the possibility of similar accumulations in the play area provide a justification for the charge probability of 1.0.

\section{Traps/Rock}

The principal style of trapping for undiscovered resources in the Kemik-Thomson play area is postulated to be incised valley-fill reservoirs in which petroleum is potentially trapped by the overlying pebble shale unit and Hue Shale mudstones, and by possible sinuosity of the incised valleys. Seismic data also indicate the potential for Thomson sandstone reservoirs to have been deposited in grabens associated with normal-fault displacements of the LCU on the crest of the Mikkelsen High.

Reservoir rocks are lithic-rich Lower Cretaceous Kemik Sandstone and Thomson sandstone, which directly overlie the LCU. Examination of well logs from the Point Thomson area shows that the Thomson sandstone is remarkably uniform in character, ranging from coarse-grained graben fill to a valleyfill facies. The potential exists for Thomson-like reservoirs to have developed in adjacent areas depending on whether carbonate-bearing Franklinian-age basement rocks were present as a sediment source. Reservoirs in the Point Thomson Field give this play a probability of 1.0 for analogous traps and reservoirs.

\section{Timing}

The formation of potential reservoirs and stratigraphic traps occurred in the Early Cretaceous (Hauterivian, 136-30 Ma; fig. 15). Significant petroleum generation and migration occurred in the range of 80 to $35 \mathrm{Ma}$ (Peters and others, 2003), indicating that petroleum migration and accumulation would have followed trap formation (fig. 15). Given this scenario, the timing probability was assigned a value of 1.0 .

\section{Kemik-Thomson Play Probabilities}

The probabilities assigned to the three play elements (charge, trap/rock, timing) were 1.0, given the fact that the Point Thomson Field exists in the Kemik-Thomson Play area. Similar attributes are believed to characterize adjacent areas; hence, we place a probability of 1.0 for the occurrence of at least one undiscovered accumulation of minimum size (5 MMBO; 100 BCFG) within the play area.

\section{Kemik-Thomson Prospect Attributes}

\section{Net Reservoir Thickness}

Estimates of net thickness of undiscovered Kemik-Thomson oil reservoirs range between $40 \mathrm{ft}$ at the minimum, $100 \mathrm{ft}$ at the median, and $300 \mathrm{ft}$ at the maximum. The maximum thickness of $300 \mathrm{ft}$ reflects the estimation that reservoirs as thick as those in the Point Thomson area may be present elsewhere along and adjacent to the Mikkelsen High (Nelson, 1999; his table PP1). The maximum gross measured thickness of the Kemik Sandstone in the play area was logged at $280 \mathrm{ft}$ in the Kemik \#1 well, although the Kemik interval in this well might be structurally thickened. The estimated median of $100 \mathrm{ft}$ is less than the average of measured Thomson sandstone thickness from wells within the Point Thomson Field area, but reflects a probable decrease in the topographic relief on the LCU away from the Mikkelsen High toward the southern boundary of the play.

\section{Area of Closure}

Estimates for area of closure, based on interpretations of seismic profiles and postulated geometry of stratigraphic traps, are 1,000 acres at the minimum, 3,000 acres at the median, and 20,000 acres at the maximum. The maximum size is based on measurements within the so-called Slugger Unit (fig. 3), which is a lease unit recognized in the northeastern part of the Central North Slope by the Alaska Division of Oil and Gas as potentially having a Kemik Sandstone reservoir. The prominent Kemik Sandstone prospect in the Slugger Unit is estimated to occupy an area of about $4 \times 8 \mathrm{mi}$, or $32 \mathrm{mi}^{2}$, hence the estimated maximum area of closure of about 20,000 acres. The minimum and median values were based on the sizes of two-dimensional offsets on the LCU, as measured on the seismic profiles, combined with an aspect ratio of 2:1 and an estimation for prospects between seismic lines. The estimates for the sizes of areas of closure were also developed using the concept that prospects could range from a field extension of the existing Point Thomson Field to the Thomson sandstone having several discrete structural and/or stratigraphic accumulations elsewhere in the play area. The field extension concept also helped constrain the area of closure to a maximum of 20,000 acres. 


\section{Porosity}

The distribution of porosities estimated for undiscovered Kemik-Thomson Play reservoirs is based on the porosity distribution measured in six wells penetrating the Thomson sandstone in the Point Thomson Field (Nelson, 1999; his fig. PP1g). The minimum, median, and maximum porosities are estimated to be 10 percent, 16 percent, and 26 percent respectively. The maximum of 26 percent reflects the concept that this value would represent the average maximum porosity of a prospect in the Thomson sandstone, 16 percent reflects the measured median, and the minimum of 10 percent porosity is what would be required to form a prospect of minimum accumulation size. Porosity in the Thomson sandstone may be a combination of preserved intergranular porosity and secondary porosity resulting from the dissolution of carbonate lithic grains and cements. Cumulative porosity distributions from well logs in four penetrations of the Kemik Sandstone show median values ranging from 3 to 10 percent (Nelson, 1999) for the very fine-grained sandstone facies. However, this facies of the Kemik Sandstone is not part of the conventional reservoir model for this play, nor did we consider the effect of fracturing on porosity and permeability.

\section{Water Saturation}

Water saturation was computed from porosity measurements, assuming a fixed water content of 6 percent that is believed to be representative of very fine-grained sandstones. However, a comparison of water saturation with the Thomson sandstone (which is also 6 percent) indicates that value may characterize a potential coarser-grained facies of the Kemik Sandstone. A water content of 6 percent was computed from geophysical logs in Point Thomson Unit \#3 well (Nelson, 1999).

The Thomson sandstone reservoir at Point Thomson Field may be overpressured, but the degree to which undiscovered reservoirs in the Kemik-Thomson Play may also be overpressured is indeterminate. The value for the Formation Volume Factor (FVF) resulting from the equation in Appendix 1 may represent a minimum owing to a lack of information on the regional pressure regime in the Thomson sandstone.

\section{Trap Fill}

Kemik and Thomson sandstone reservoirs are estimated to have high trap fill percentage because of their proximity to Hue Shale source rocks, the relatively small trap size, and the possibility for stratigraphic traps being close to source rocks. The estimated distribution of trap fill-60 percent filled at the minimum, 85 percent filled at the median, and 100 percent filled at the maximum - reflects our interpretation that stratigraphic traps would be nearly filled with oil or gas, especially in view of the fact that the porosity of Thomson sandstones penetrated in the Point Thomson Field is nearly 100 percent saturated with petroleum.

\section{Trap Depth}

Estimates for the distribution of undiscovered trap depths is based upon examination and interpretation of all available depth-converted seismic data. For potential oil reservoirs, the distribution ranges between a minimum of $10,000 \mathrm{ft}$, a median of $14,000 \mathrm{ft}$, and a maximum of $16,000 \mathrm{ft}$ in the play area. For potential gas reservoirs, the distribution ranges between a minimum of $10,000 \mathrm{ft}$, a median of $14,000 \mathrm{ft}$, and a maximum of $18,000 \mathrm{ft}$ in the southern part of the play area.

\section{Number of Prospects}

The number of oil prospects estimated for the KemikThomson Play range from a minimum of 30 (Appendix 1), which reflects the most reliable interpretations of the seismic data set, to 60 at the median, which includes estimates for all on-line prospects, and to a maximum of 100 , which includes the possibility of stratigraphic traps and possible between-line prospects within and beyond the available seismic-data grid. The estimate of the number of oil prospects was constrained by the suspected limited number of potential reservoirs resulting from decreased erosion on the LCU in the southern part of the play. Also, thermal conditions in that area favored generation of gas. Numbers of gas prospects were estimated to be 30 at the minimum, 60 at the median, and 100 at the maximum. Combining potential prospects for oil and gas, the total number of prospects for the Kemik-Thomson Play is estimated to be 60 at the minimum, 120 at the median, and 200 at the maximum. Given about 120 prospects at the median (60 for oil, 60 for gas; Appendix 1), the prospect probability indicates that 9 percent will be successful, amounting to a total of 10 accumulations, of which 5 are expected to be oil and 5 are expected to be gas.

An important part of the estimation of prospects was the consideration of the Lower Cretaceous Muddy Sandstone in the Powder River Basin, Wyoming, as a geological analog (fig. 14). Reservoirs of the Muddy Sandstone have been interpreted as incised valley-fill deposits, with clastic detritus filling topographic relief on an erosional surface cut into the Lower Cretaceous Thermopolis-Skull Creek Shale (Dolton and Fox, 1996). The Muddy Sandstone reservoirs are a complex association of facies including fluvial, deltaic, and shallow marine sandstones representing transgressive and minor regressive phases of deposition. The source rock is the overlying Mowry Shale, which has the same stratigraphic position with respect to the Muddy as do the pebble shale unit/Hue Shale with respect to the Kemik Sandstone and Thomson sandstone reservoirs. A plot of oil accumulation sizes relative to discovery date for Muddy fields illustrates a typical stratigraphic play in that a few large fields have been found, but most fields are relatively small (fig. 13). Eliminating fields smaller than $5 \mathrm{MMBO}$ (minimum accumulation size for this assessment), about 30 accumulations have been discovered in the Muddy Sandstone. With a success ratio of about 50 percent, the total number of Muddy prospects would roughly have been about 80 or 90 . This compares well with the estimation of about 120 prospects at the median in our assessment of the Kemik-Thomson Play. 


\section{Kemik-Thomson Prospect Probabilities}

For potential oil prospects, the probability that a random prospect in this play would be charged with hydrocarbons was estimated to be 0.9 , given that as many as four source rocks may have contributed petroleum. The probability that a random oil prospect having a reservoir that would yield $5 \mathrm{MMBO}$ was assigned a probability of 0.1 , and the probability that generation and migration of petroleum occurred after trap and reservoir formation was given a value of 1.0. These probabilities yielded a total prospect probability for oil accumulations in the Kemik-Thomson Play of 0.09, which means that a random prospect has a 9-percent chance of being successful. For gas prospects, the probability for the charging of potential reservoirs was high, at 0.9 , but the occurrence of adequate reservoirs was low, at 0.1 . The timing for a random prospect was considered to be 1.0. Combined, these provide a gas-prospect probability of 0.09 , the same as for oil prospects.

\section{Assessment Results}

The assessment results for undiscovered oil and gas resources in the Kemik-Thomson Play of the Central North Slope, Alaska, are shown in table 1, which is reproduced from U.S. Geological Survey Central North Slope Assessment Team (2005). For the Kemik-Thomson Play, the mean undiscovered oil resource was estimated at $252 \mathrm{MMBO}$, ranging from a 95-percent chance (F95) of $46 \mathrm{MMBO}$ to a 5-percent chance
(F5) of 556 MMBO. The mean undiscovered gas resource was estimated to be 2,762 BCFG, with a 95-percent chance (F95) of 549 BCFG and a 5-percent chance (F5) of 5,933 BCFG. The range of oil and gas resource estimates mainly reflects the geologic uncertainty of adequate reservoirs being present in the play area.

\section{Summary}

A geologic model was developed for potential oil and gas accumulations in reservoirs of the Lower Cretaceous Kemik Sandstone and Thomson sandstone in the Central North Slope of Alaska. The validity of the model depends largely on the presence of coarse-grained detritus that accumulated in valleys incised on the LCU during erosion of various stratigraphic units beneath the unconformity, thus forming discontinuous deposits that were then overlain by the pebble shale unit or the Hue Shale, which act as both seals and source rocks. Other potential source rocks for these reservoirs include the Triassic Shublik Formation, Jurassic Kingak Formation, and the Cretaceous-Tertiary Canning Formation, leading to the definition of the Triassic-Tertiary Composite Petroleum System that incorporates the Kemik-Thomson Play. Analysis of all available seismic and well data, in addition to examination of outcrops in the field, led to the distribution of values for geologic parameters for prospects that formed the basis for the resource assessment.

Table 1. Assessment results for undiscovered conventional oil and gas resources in the Kemik-Thomson Play, Central North Slope, Alaska.

[MMBO, million barrels of oil; BCFG, billion cubic feet of gas; MMBNGL, million barrels of natural gas liquids. Results shown are fully risked estimates. Gas volumes associated with oil fields are shown on the "Oil" row and nonassociated gas volumes on the "Gas" row. For gas fields, all liquids are included under NGL (natural-gas liquids) category. F95 denotes a 95-percent chance of at least the amount tabulated. Other fractiles are defined similarly. Fractiles are additive under the assumption of perfect positive correlation. Gray shading indicates not applicable]

\begin{tabular}{|c|c|c|c|c|c|c|c|c|c|c|c|c|c|}
\hline \multirow{2}{*}{$\begin{array}{l}\text { Petroleum System } \\
\text { and Play name }\end{array}$} & \multirow{2}{*}{$\begin{array}{l}\text { Field } \\
\text { type }\end{array}$} & \multicolumn{12}{|c|}{$\begin{array}{c}\text { Total undiscovered resources } \\
\text { Gas (BCFG) }\end{array}$} \\
\hline & & F95 & F50 & F5 & Mean & F95 & F50 & F5 & Mean & F95 & F50 & F5 & Mean \\
\hline \multicolumn{14}{|c|}{$\begin{array}{l}\text { Triassic-Tertiary Composite } \\
\text { Petroleum System }\end{array}$} \\
\hline \multirow{2}{*}{ Kemik-Thomson Play } & Oil & 46 & 222 & 556 & 252 & 83 & 400 & 1,002 & 454 & 4 & 18 & 46 & 21 \\
\hline & Gas & & & & & 466 & 2,075 & 4,931 & 2,308 & 6 & 27 & 64 & 30 \\
\hline $\begin{array}{l}\text { Total Conventional } \\
\text { Resources }\end{array}$ & & 46 & 222 & 556 & 252 & 549 & 2,475 & 5,933 & 2,762 & 10 & 45 & 110 & 51 \\
\hline
\end{tabular}




\section{References Cited}

Alaska Department of Natural Resources, 2003, 2003 Oil and Gas Report: Alaska Department of Natural Resources, Division of Oil and Gas, six sections plus tables.

Bird, K.J., Griscom, S.B., Bartsch-Winkler, S., and Giovannetti, D.M., 1987, Petroleum reservoir rocks, in Bird, K.J., and Magoon, L.B., eds., Petroleum geology of the northern part of the Arctic National Wildlife Refuge, northeastern Alaska: U.S. Geological Survey Bulletin 1778, p. 79-99.

Carman, G.J., and Hardwick, P., 1983, Geology and regional setting of the Kuparuk oil field, Alaska: American Association of Petroleum Geologists Bulletin, v. 67, no. 6, p. 1014-1031.

Dalrymple, R.W., Boyd, R., and Zaitlin, B.A., 1994, History of research, types and internal organization of incised valley systems - introduction to the volume, in Dalrymple, R.W., Boyd, R., and Zaitlin, B.A., eds., Incised valley systemsorigin and sedimentary sequences: Society of Economic Paleontologists and Mineralogists Special Publication No. 51, p. 3-10.

Detterman, R.L., Reiser, H.N., Brosge, W.P., and Dutro, J.T., Jr., 1975, Post-Carboniferous stratigraphy, northeastern Alaska: U.S. Geological Survey Professional Paper 886, $46 \mathrm{p}$.

Dolton, G.L., and Fox, J.E., 1996, Powder River Basin Province (033), in Gautier, D.L., Dolton, G.L., Takahashi, K.I., and Varnes, K.L., eds., 1995 National Assessment of United States oil and gas resources-results, methodology, and supporting data: U.S. Geological Survey Digital Data Series DDS-30, one CD-ROM.

Gautier, D.L., 1987, Petrology of Cretaceous and Tertiary reservoir sandstones in the Point Thomson area, in Bird, K.J., and Magoon, L.B., eds., Petroleum geology of the northern part of the Arctic National Wildlife Refuge, northeastern Alaska: U.S. Geological Survey Bulletin 1778, p. 117-122.

Halgedahl, S.L., and Jarrard, R. D., 1987, Paleomagnetism of the Kuparuk River Formation from oriented drill core: evidence for rotation of the Arctic Alaska plate, in Tailleur, I., and Weimer, P., eds., Alaskan North Slope Geology, Volume 2: Society of Economic Paleontologists and Mineralogists, Pacific Section, Book 50, p. 581-617.

Hubbard, R.J., Edrich, S.P., and Rattey, R.P., 1987, Geologic evolution and hydrocarbon habitat of the "Arctic Alaska microplate", in Tailleur, I., and Weimer, P., eds., Alaskan North Slope Geology, Volume 2: Society of Economic Paleontologists and Mineralogists, Pacific Section, Book 50, p. $797-830$.
Keller, A.S., Morris, R.H., and Detterman, R.L., 1961, Geology of the Shaviovik and Sagavanirktok Rivers region, Alaska: U.S. Geological Survey Professional Paper 303-D, p. 169-222.

Knock, D.G., 1986, Thirty-seven measured sections of Lower Cretaceous Kemik Sandstone, northeastern Alaska: Alaska Division of Mining and Geology, Public-Data File 86-86B, Fairbanks, Alaska, 22 p.

Knock, D.G., 1987a, Lithofacies, depositional setting, and petrography of the Kemik Sandstone, Arctic National Wildlife Refuge (ANWR), northeastern Alaska: Master's Thesis, University of Alaska, Fairbanks, Alaska, 135 p.

Knock, D.G., 1987b, Depositional setting and provenance of Upper Neocomian Kemik Sandstone, Arctic National Wildlife Refuge (ANWR), northeastern Alaska, in Tailleur, I., and Weimer, P., eds., Alaskan North Slope Geology, Volume 2: Society of Economic Paleontologists and Mineralogists, Pacific Section, Book 50, p. 868.

Leffingwell, E. de K., 1919, The Canning River region, northern Alaska: U.S. Geological Survey Professional Paper 109, $251 \mathrm{p}$.

Magoon, L.B., Bird, K.J., Burruss, R.C., Hayba, D., Houseknecht, D.W., Keller, M.A., Lillis, P.G., and Rowan, E.L., 1998, Evaluation of hydrocarbon charge and timing using the petroleum system, in ANWR Assessment Team, The oil and gas potential of the 1002 Area, Arctic National Wildlife Refuge, Alaska: U.S. Geological Survey Open-File Report 98-43, Chapter PS.

Magoon, L.B., Lillis, P. G., Bird, K.J., Lampe, C., and Peters, K.E., 2003, Alaskan North Slope petroleum systems: U.S. Geological Survey Open-File Report 03-324, 3 p.

Masterson, W.D., and Paris, C.E., 1987, Depositional history and reservoir description of the Kuparuk River Formation, North Slope, Alaska, in Tailleur, I., and Weimer, P., eds., Alaskan North Slope Geology, Volume 1: Society of Economic Paleontologists and Mineralogists, Pacific Section, Book 50, p. 95-107.

Melvin, J., 1987, Kemik Sandstone: inner shelf sand from northeast Alaska, in Tailleur, I., and Weimer, P., eds., Alaskan North Slope Geology, Volume 1: Society of Economic Paleontologists and Mineralogists, Pacific Section, Book 50, p. 432 .

Molenaar, C.M., Bird, K.J., and Kirk, A.R., 1987, Cretaceous and Tertiary stratigraphy of northeastern Alaska, in Tailleur, I., and Weimer, P., eds., Alaskan North Slope Geology, Volume 2: Society of Economic Paleontologists and Mineralogists, Pacific Section, Book 50, p. 513-528. 
Mull, C.G., 1987, Kemik Sandstone, Arctic National Wildlife Refuge, northeastern Alaska, in Tailleur, I., and Weimer, P., eds., Alaskan North Slope Geology, Volume 1: Society of Economic Paleontologists and Mineralogists, Pacific Section, Book 50, p. 405-431.

Nelson, P., 1999, Petrophysical properties, in ANWR Assessment Team, The oil and gas potential of the 1002 area, Arctic National Wildlife Refuge, Alaska: U.S. Geological Survey Open-File Report 98-34, Chapter PP.

Noonan, W.G., 1987, Post-Ellesmerian depositional sequences of the North Slope subsurface, in Tailleur, I., and Weimer, P., eds., Alaskan North Slope Geology, Volume 1: Society of Economic Paleontologists and Mineralogists, Pacific Section, Book 50, p. 459-477.

Peters, K.E., Bird, K.J., Keller, M.A., Lillis, P.G., and Magoon, L.B., 2003, Distribution, richness, quality, and thermal maturity of source rock units on the North Slope of Alaska: U.S. Geological Survey Open-File Report 03-328, $3 \mathrm{p}$.

Posamentier, H.W., and Morris, W.R., 2000, Aspects of the stratal architecture of forced regressive deposits, in Hunt, D., and Gawthorpe, R.L., eds., Sedimentary response to forced regression: Geological Society of London Special Publication No. 172, p. 19-46.

Reifenstuhl, R.R., 1995, Lithofacies, petrology, and petrophysics of the Kemik Sandstone (Lower Cretaceous), eastern Arctic Slope, Alaska, in Combellick, R.A., and Tannian, F., eds., Short Notes on Alaska Geology, 1995: Alaska Division of Geological and Geophysical Surveys Professional Report 117, p. 53-67.

Schenk, C.J., and Houseknecht, D.W., 1999a, Thomson Play, in ANWR Assessment Team, The oil and gas potential of the 1002 area, Arctic National Wildlife Refuge, Alaska: U.S. Geological Survey Open-File Report 98-34, Chapter P4.
Schenk, C.J., and Houseknecht, D.W., 1999b, Kemik Play, in ANWR Assessment Team, The oil and gas potential of the 1002 area, Arctic National Wildlife Refuge, Alaska: U.S. Geological Survey Open-File Report 98-34, Chapter P5.

Schenk, C.J., and Houseknecht, D.W., 1999c, Sedimentology of the Kemik and Thomson sandstones in the western part of the Arctic National Wildlife Refuge 1002 area, Alaska, in ANWR Assessment Team, The oil and gas potential of the 1002 area, Arctic National Wildlife Refuge, Alaska: U.S. Geological Survey Open-File Report 98-34, Chapter TK.

Schenk, C.J., and Houseknecht, D.W., 2002, Assessment of undiscovered technically recoverable oil and gas resources in the Thomson sandstone and Kemik Sandstone, ANWR 1002 Area [abs.]: American Association of Petroleum Geologists Bulletin, v. 86, no. 6, p. 1159.

U.S. Geological Survey Central North Slope Assessment Team, 2005, Oil and gas assessment of the Central North Slope, Alaska, 2005: U.S. Geological Survey Fact Sheet 2005-3043, April, 2005. [Also available at http://pubs.usgs.gov/fs/2005/3043/, accessed on March 2, 2006]

Van Wagoner, J.C., Mitchum, R.M., Campion, K.M., and Rahmanian, V.D., 1990, Siliciclastic sequence stratigraphy in well logs, cores and outcrops: American Association of Petroleum Geologists Methods in Exploration Series, No. 7, $55 \mathrm{p}$.

Zaitlin, B.A., Dalrymple, R.W., and Boyd, R., 1994, The stratigraphic organization of incised-valley systems associated with relative sea-level change, in Dalrymple, R.W., Boyd, R., and Zaitlin, B.A., eds., Incised valley systemsorigin and sedimentary sequences: Society of Economic Paleontologists and Mineralogists Special Publication No. 51, p. 45-60. 


\section{Appendix 1.}

Geologic input data form for the assessment of the Kemik-Thomson Play. Yellow boxes are those in which geologic input was required from the assessor. The geologic input is used in the calculation of estimated volumes of undiscovered oil and gas resources. 


\section{Alaskan Assessment Form $\quad$ Rev: $5-0 c t-04$ \\ PLAY: Kemik-Thomson \\ Oil Play Area: $\quad 1803$ thousands of acres}

\section{OIL ACCUMULATION ATTRIBUTE DISTRIBUTIONS}

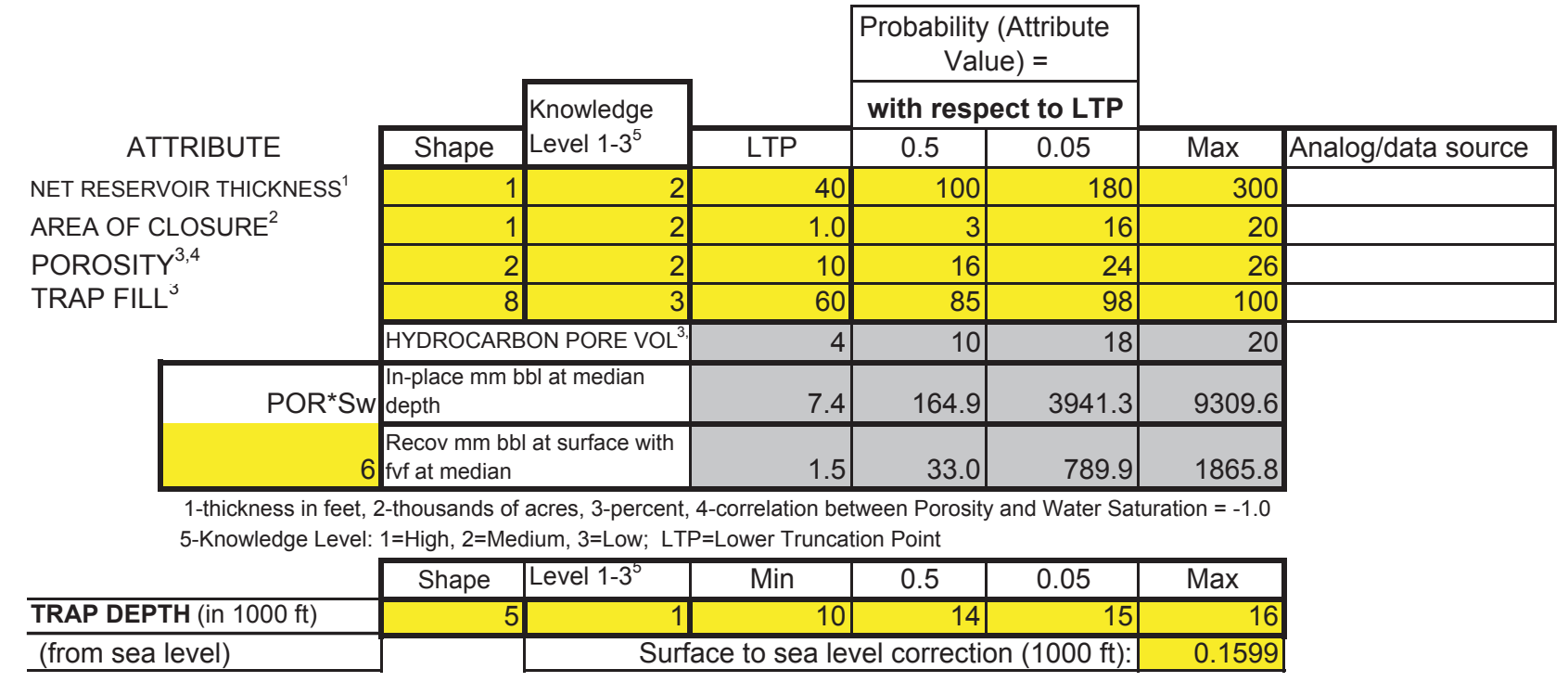

\section{OIL ACCUMULATION CHARACTERISTICS}

Oil recovery factor $\%$

Type of reservoir-drive (check any that apply):

$$
\text { Water: }
$$

Depletion: $\mathrm{x}$

Gas expansion: $\mathrm{x}$

FVF (Formation volume factor, rb/stb):

$$
2.00 \text { (at median depth) }
$$
(see OilDet sheet)

$\operatorname{NGLR}$ (Natural gas liquids to associated gas ratio, bbls/million cu.ft., at stp) $=4.5985^{*} \exp \left(.1711^{*} T D\right.$ )

Oil quality parameters:

50.5 (at median depth)

$$
\begin{aligned}
& \text { API gravity } \\
& \text { Oil Grav (ratio) } \\
& \text { Sulfur content of oil }
\end{aligned}
$$

Associated gas quality parameters:

Hydrogen sulfide \%

CO2 contamination \%

Other inert gases:

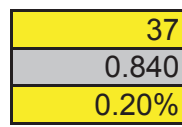

\section{7}

$20 \%$

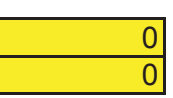

Name:

Name:

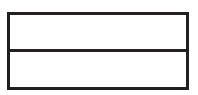

Percent:

Percent:

\begin{tabular}{|c|c|c|}
\hline BEGIN & PEAK & END \\
\hline 140 & & 130 \\
\hline 100 & 65 & 45 \\
\hline
\end{tabular}

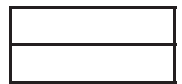

TIME OF TRAP DEVELOPMENT

STRATIGRAPHIC COMPONENT (Ma)

STRUCTURAL COMPONENT (Ma)

Assessor's Name: $\quad$ CJS, DWH

Date of Data Entry MM/DD/YYYY:

Date of Simulation Run MM/DD/YYYY: 


\section{Alaskan Assessment Form}

5-Oct-04

PLAY: Kemik-Thomson

Gas Play Area:

1803 thousands of acres

NONASSOCIATED GAS ACCUMULATION ATTRIBUTE DISTRIBUTIONS

\begin{tabular}{|c|c|c|c|c|c|c|c|}
\hline \multirow{3}{*}{ ATTRIBUTE } & & \multirow{3}{*}{$\begin{array}{l}\text { Knowledge } \\
\text { Level } 1-3^{5}\end{array}$} & \multirow[b]{3}{*}{ LTP } & \multirow{2}{*}{\multicolumn{2}{|c|}{$\begin{array}{c}\text { Probability (Attribute } \\
\text { Value) = } \\
\text { with respect to LTP }\end{array}$}} & \multirow[b]{3}{*}{ Max } & \multirow[b]{3}{*}{ Analog/data source } \\
\hline & & & & & & & \\
\hline & Shape & & & 0.5 & 0.05 & & \\
\hline \multirow{5}{*}{$\begin{array}{l}\text { NET RESERVOIR THICKNESS } \\
\text { AREA OF CLOSURE }^{1} \\
\text { POROSITY }^{3,4} \\
\text { TRAP FILL }^{3}\end{array}$} & 1 & 2 & 40 & 100 & 180 & 300 & \\
\hline & 1 & 2 & 1 & 3 & 16 & 20 & \\
\hline & 2 & 2 & 10 & 16 & 24 & 26 & \\
\hline & $\begin{array}{r}8 \\
\end{array}$ & 3 & 60 & 85 & 98 & 100 & \\
\hline & \multicolumn{2}{|c|}{ HYDROCARBON PORE VOL ${ }^{3,4}$} & 4 & 10 & 18 & 20 & \\
\hline POR*Sw & \multicolumn{2}{|c|}{\begin{tabular}{|c|} 
In-place bcf \\
\end{tabular}} & 0.04 & 1.11 & 22.13 & 52.27 & \\
\hline & \multicolumn{2}{|c|}{$\begin{array}{l}\text { Recov bcf at surface at minium } \\
\text { depth }\end{array}$} & 6.7 & 176.8 & 3522.5 & 8320.4 & \\
\hline & \multicolumn{2}{|c|}{$\begin{array}{l}\text { Recov bcf at surface at median } \\
\text { depth }\end{array}$} & 8.2 & 218.8 & 4358.8 & 10295.7 & \\
\hline & \multicolumn{2}{|c|}{$\begin{array}{l}\text { Recov bcf at surface at maxium } \\
\text { depth }\end{array}$} & 8.7 & 231.4 & 4611.1 & 10891.6 & \\
\hline \multicolumn{7}{|c|}{$\begin{array}{l}\text { 1-thickness in feet, 2-thousands of acres, 3-percent, 4-correlation between Porosity and Water Saturation = }-1.0 \\
\text { 5-Knowledge Level: } 1=\text { High, 2=Medium, 3=Low; LTP=Lower Truncation Point }\end{array}$} & \\
\hline & Shape & Level $1-3^{5}$ & Min & 0.5 & 0.05 & Max & \\
\hline \multirow{2}{*}{$\begin{array}{l}\text { TRAP DEPTH (in } 1000 \mathrm{ft} \text { ) } \\
\text { (from sea level) }\end{array}$} & 2 & 1 & 12 & 14 & 16 & 18 & \\
\hline & \multicolumn{5}{|c|}{ Enter surface to sea level correction $(1000 \mathrm{ft})$ : } & 0.1599 & \\
\hline
\end{tabular}

\section{NONASSOCIATED GAS ACCUMULATION CHARACTERISTICS}

NA Gas recovery factor \%

Type of reservoir-drive (check any that apply):

Water: expansion: $\mathrm{X}$
Natural gas liquids plus condensate to non-associated gas (bbls/million cf) (in place)

70 NGL-NAG $=1.785^{*} \mathrm{TD}$

Nonassociated gas quality parameters:

Hydrogen sulfide \%

CO2 contamination \%

Other inert gases:

Gas fvf

$$
\begin{aligned}
& \text { Name: } \\
& \text { Name: }
\end{aligned}
$$
227.4 min depth 281.4 median depth 297.7 max depth 25.0 (at median)

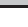
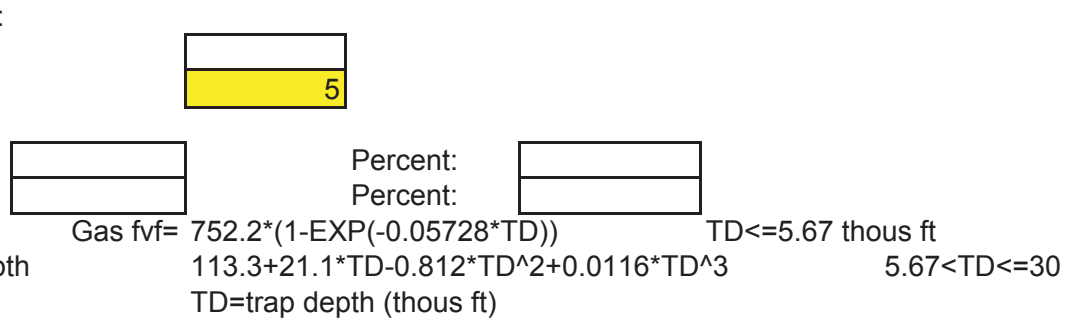

For Nonassociated Gas Accumulation: TIME OF TRAP DEVELOPMENT
STRATIGRAPHIC COMPONENT (Ma)
STRUCTURAL COMPONENT (Ma)

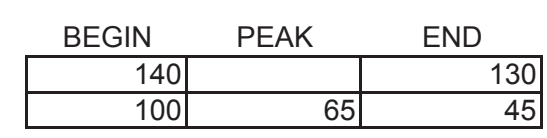

\begin{tabular}{l|r|} 
Assessor's Name: & \multicolumn{2}{|l|}{ CJS, DWH } \\
Date of Data Entry MM/DD/YYYY: & $10 / 5 / 2004$ \\
& \\
Date of Simulation Run MM/DD/YYYY: & $10 / 11 / 2004$ \\
\hline
\end{tabular} 


\section{Alaskan Assessment Form \\ PLAY: \\ Kemik-Thomson \\ Oil Play Area: $\quad 1803$ thousands of acres \\ Gas Play Area: $\quad 1803$ thousands of acres}

Rev: 5-Oct-04

\section{OIL PROSPECTS}

MINIMUM ACCUMULATION SIZE, MAS

$5[\mathrm{~mm}$ bbl, recoverable

\begin{tabular}{|c|c|c|c|c|c|c|}
\hline & & Knowledge & & $\begin{array}{r}\text { Prob ( } \\
\text { Prospect }>\end{array}$ & $\begin{array}{l}\text { m. of } \\
\text { Value) }=\end{array}$ & \\
\hline & Shape & Level $1-3^{5}$ & Min & 0.5 & 0.05 & $\operatorname{Max}$ \\
\hline NUM OF PROSPECTS & 2 & 3 & 30 & 60 & 80 & 100 \\
\hline 5-Knowledge Level: 1=High, & dium, $3=\mathrm{LO}$ & & & & & \\
\hline Size thousands acres ( $\mathrm{m}$ & an closure & & 75 & 150 & 200 & 250 \\
\hline percent of oil & area & & 4.2 & 8.3 & 11.1 & 13.9 \\
\hline
\end{tabular}

\section{NONASSOCIATED GAS PROSPECTS}

MINIMUM ACCUMULATION SIZE, MAS

$100 \mid$ bcf, recoverable

\begin{tabular}{|c|c|c|c|c|c|c|}
\hline \multirow[b]{3}{*}{ NUM OF PROSPECTS } & \multirow[b]{2}{*}{ Shape } & \multirow{2}{*}{$\begin{array}{l}\text { Knowledge } \\
\text { Level } 1-3^{5}\end{array}$} & \multirow[b]{2}{*}{ Min } & \multicolumn{2}{|c|}{$\begin{array}{c}\text { Prob (Num. of } \\
\text { Prospect }>=\text { Value })=\end{array}$} & \multirow[b]{2}{*}{ Max } \\
\hline & & & & 0.5 & 0.05 & \\
\hline & 2 & 3 & 30 & 60 & 80 & 100 \\
\hline \multicolumn{7}{|l|}{ 5-Knowledge Level: $1=$ High, $2=1$} \\
\hline \multirow{2}{*}{\multicolumn{3}{|c|}{$\begin{array}{c}\text { Size thousands acres (median closure): } \\
\text { percent of gas play area }\end{array}$}} & 90 & 180 & 240 & 300 \\
\hline & & & 5.0 & 10.0 & 13.3 & 16.6 \\
\hline
\end{tabular}

\section{Closure Size Check - Oil + NA Gas Areas - Median and Max Closure}

Size thousands acres (median closure): percent of total play area:

\begin{tabular}{|r|r|r|r|}
\hline 165 & 330 & 440 & 550 \\
\hline 4.6 & 9.2 & 12.2 & 15.3 \\
\hline
\end{tabular}

Assessor's Name: CJS, DWH

Date of Data Entry MM/DD/YYYY:

Date of Simulation Run MM/DD/YYYY: 
Alaskan Assessment Form

5-Oct-04

Play: Kemik-Thomson

\section{PROSPECT \& PLAY RISKING}

\begin{tabular}{|c|c|c|c|c|c|}
\hline & ATTRIBUTES & \multicolumn{4}{|c|}{$\begin{array}{l}\text { OF FAVORABLE } \\
\text { Play }\end{array}$} \\
\hline \multirow{3}{*}{$\begin{array}{l}\text { PLAY } \\
\text { ATTRIBUTES }\end{array}$} & CHARGE (C) & 1 & & & \\
\hline & TRAP/ROCK (T) & 1 & & & \\
\hline & TIMING $(F)$ & 1 & & & \\
\hline \multicolumn{3}{|c|}{ Probability that play contains at least 1 reservoir $>=$ minimum accumulation size $(C x T \times F)$} & \multicolumn{3}{|c|}{1} \\
\hline & \multicolumn{5}{|c|}{ Note: Specification of both Oil and Gas play risk attributes implies definition of separate oil \& gas plays } \\
\hline \multirow{4}{*}{$\begin{array}{l}\text { PROSPECT } \\
\text { ATTRIBUTES }\end{array}$} & \multirow{4}{*}{$\begin{array}{l}\text { CHARGE }(\mathrm{c}) \\
\text { TRAP/ROCK }(\mathrm{t}) \\
\text { TIMING }(\mathrm{f})\end{array}$} & Oil & \multicolumn{3}{|c|}{ NA Gas } \\
\hline & & 0.9 & & 0.9 & \\
\hline & & 0.1 & & 0.1 & \\
\hline & & 1 & & 1 & \\
\hline \multicolumn{3}{|c|}{ Probability that a randomly chosen prospect $>=$ minimum accumulation size is favorable (cxtxf) } & 0.09 & & 0.09 \\
\hline \multicolumn{3}{|c|}{ Play Attributes x Prospect Attributes (CxTxFxcxtxf) } & 0.090 & & 0.090 \\
\hline
\end{tabular}

Allocation (percent):

\begin{tabular}{|c|c|c|c|c|}
\hline & Land Area & Oil Vol & Gas Vol \\
\hline \multicolumn{5}{|c|}{ Percent state } \\
\hline \multirow[t]{2}{*}{ State } & Onshore & 82 & & \\
\hline & Offshore & 18 & 100 & 100 \\
\hline \multicolumn{2}{|c|}{ Percent native } & 0 & 0 & 0 \\
\hline \multirow[t]{2}{*}{ Native } & Onshore & & & \\
\hline & Offshore & 0 & 0 & 0 \\
\hline \multicolumn{2}{|c|}{ Total percent } & 100 & 100 & 100 \\
\hline
\end{tabular}

Assessor's Name:

Date of Data Entry MM/DD/YYYY:

CJS, DWH

Date of Simulation Run MM/DD/YYYY:

$10 / 5 / 2004$

$10 / 11 / 2004$

Publishing support provided by:

Denver Publishing Service Center

Manuscript approved for publication August 12, 2008

Edited by Chelsea Carr

Designed and prepared by Margo VanAlstine

For more information concerning this publication, contact:

Team Chief Scientist, USGS Central Energy Resources

Box 25046, Mail Stop 939

Denver, CO 80225

(303) 236-1647

Or visit the Central Energy Resources Team site at:

http://energy.cr.usgs.gov/ 
